Article

\title{
Life Cycle Energy and Environmental Assessment of the Thermal Insulation Improvement in Residential Buildings
}

\author{
Maria Anna Cusenza ${ }^{1}$, Teresa Maria Gulotta ${ }^{1}$, Marina Mistretta ${ }^{2, *(\mathbb{D})}$ and Maurizio Cellura ${ }^{1}$ \\ 1 Dipartimento di Ingegneria, Università degli Studi di Palermo, Viale delle Scienze Ed.9, 90128 Palermo, Italy; \\ mariaanna.cusenza@unipa.it (M.A.C.); teresamaria.gulotta@unipa.it (T.M.G.); \\ maurizio.cellura@unipa.it (M.C.) \\ 2 Dipartimento di Patrimonio, Architettura, Urbanistica, Università degli Studi Mediterranea di Reggio, \\ Calabria, Salita Melissari, 89124 Reggio Calabria, Italy \\ * Correspondence: marina.mistretta@unirc.it
}

check for updates

Citation: Cusenza, M.A.; Gulotta, T.M.; Mistretta, M.; Cellura, M. Life Cycle Energy and Environmental Assessment of the Thermal Insulation Improvement in Residential

Buildings. Energies 2021, 14, 3452.

https://doi.org/10.3390/en14123452

Academic Editor: Chi-Ming Lai

Received: 7 May 2021

Accepted: 9 June 2021

Published: 10 June 2021

Publisher's Note: MDPI stays neutral with regard to jurisdictional claims in published maps and institutional affiliations.

Copyright: (c) 2021 by the authors. Licensee MDPI, Basel, Switzerland. This article is an open access article distributed under the terms and conditions of the Creative Commons Attribution (CC BY) license (https:// creativecommons.org/licenses/by/ $4.0 /)$.

\begin{abstract}
The refurbishment of the building stock is a key strategy towards the achievement of the climate and energy goals of the European Union. This study aims at evaluating the energy and environmental impacts associated with retrofitting a residential apartment to improve its vertical envelope thermal insulation. Two insulation materials, stone wool and cellulose fibers, are compared. The life cycle assessment methodology is applied assuming $1 \mathrm{~m}^{2}$ of retrofitted vertical envelope as functional unit. Moreover, to estimate the net energy and environmental benefits achievable in the retrofitted scenario compared with the non-retrofitted one, a second analysis is performed in which the system boundaries are expanded to include the building operational phase, and $1 \mathrm{~m}^{2}$ of walkable floor per year is assumed as reference. The results show that the use of cellulose fibers involve lower impacts in most of the assessed categories compared to stone wool, except for abiotic resource depletion. In detail, the use of cellulose fibers allows to reduce the impact on climate change up to $20 \%$ and the consumption of primary energy up to $10 \%$. The evaluation of the net energy and environmental benefits shows the effectiveness of the retrofit energy policies.
\end{abstract}

Keywords: building retrofit; thermal insulation; bio-based materials; energy; life cycle assessment; sustainability

\section{Introduction}

The building sector accounts for about $40 \%$ of energy consumption and $36 \%$ of the $\mathrm{CO}_{2}$ emissions of the European Union (EU [1]), it is responsible for over $50 \%$ of the use of extracted materials [2] and for 38\% of the waste generated [3]. Therefore, improving the environmental performances of the building sector is crucial for achieving the European targets in terms of reduction of greenhouse gas (GHG) emissions and energy efficiency [4], and for the transition towards a true circular development.

The EU building stock has a large potential of energy and emissions savings, since a large share of buildings were built before any energy efficiency regulation was actually in force [1]. EU policy makers have long recognised the key role of the buildings retrofit in the transition towards a more sustainable economic system. Directive 2018/844/EU [1] highlights the need of a long-term strategy to support the renovation of the national building stock into a highly energy efficient and decarbonised one by 2050. Recently, as underlined by the European Commission in the European Green Deal action plan, the application of the energy performance legislation in the building sector is of paramount importance to achieve the Agenda 2030 Sustainable Development Goals [5] also through the widespread diffusion of positive energy districts and zero energy communities [6,7], the application of circular economy strategies at the urban level [8], the use of climateresilient, low-impact construction techniques. According to the European Commission Communication on the renovation wave $(\operatorname{COM}(2020) 662)$ by 2030 the EU should reduce 
buildings' GHGs by $60 \%$, their final energy consumption by $14 \%$ and energy consumption for heating and cooling by $18 \%$, in order to cut the emission of GHGs in the EU by at least $55 \%$ compared to 1990 [9]. Matching these targets requires at least double the annual energy renovation rate of residential and non-residential buildings by 2030 [9].

In this framework, the use of a life cycle approach for the assessment of the potential energy and environmental impacts and benefits of the retrofit actions can provide an effective support to the identification of the most effective strategies towards high performance buildings. The life cycle approach allows assessing the whole life cycle of a product/process/system and the impacts in a wide range of environmental categories avoiding the burden shifting from one stage of the life cycle to another and/or from one environmental impact category to another $[10,11]$.

In this context, the authors apply the life cycle assessment (LCA) methodology according to the ISO14040 and ISO14044 standards $[12,13]$ with the aim to assess the potential life cycle energy and environmental impacts and benefits due to the installation of thermal insulation in the vertical envelope of residential buildings. Two insulation materials are compared, a bio-based (cellulose fibers) and a conventional material (stone wool). Moreover, to estimate the net energy and environmental benefits achievable the retrofit scenario is compared with a non-retrofitted scenario. Finally, to provide a more effective description of the energy and environmental performances and an easy comparison of the two alternatives, the energy and environmental impacts were complemented with payback time $\left(\mathrm{I}_{\mathrm{PBT}}\right)$ indices calculated for all the impact categories.

The results can support policy makers to plan building renovation strategies based on reliable results on the achievable net energy and environmental benefits. The comparison of a bio-based material with a conventional material for thermal insulation can support the integration of the circular and bio-economy principles in the building renovation [14].

\section{Literature Review}

Several LCAs on buildings have been carried out in the last decades. However, an extended literature review performed by Cabeza et al. [15] highlights that there are few LCAs focused on building retrofit actions. Moreover, based on authors knowledge, few LCAs compare the environmental performances of different thermal insulation materials.

Llantoy et al. [16] developed a LCA aimed at analysing and comparing the environmental impacts of different insulation materials: polyurethane (thermal conductivity $0.028 \mathrm{~W} /(\mathrm{m} \mathrm{K})$ ), extruded polystyrene (thermal conductivity $0.034 \mathrm{~W} /(\mathrm{m} \mathrm{K})$ ), and glass wool (thermal conductivity $0.035 \mathrm{~W} /(\mathrm{m} \mathrm{K})$ ). The insulation materials are installed in four houses, located at an experimental site in Spain. The system boundaries included manufacturing and operational phases. The impact assessment results-expressed in Recipe points and GWP-pointed out that mineral wool presented better environmental performance, and extruded polystyrene presented a similar environmental impact to polyurethane; however, extruded polystyrene presented the worst environmental performance of all materials evaluated.

Sierra-Pérez et al. [17] performed a LCA to assess the environmental impacts of façade systems in which different insulation materials were employed: stone wool (thermal conductivity $0.039 \mathrm{~W} /(\mathrm{m} \mathrm{K})$ ), glass wool (thermal conductivity $0.036 \mathrm{~W} /(\mathrm{m} \mathrm{K}))$, expanded polystyrene (thermal conductivity $0.035 \mathrm{~W} /(\mathrm{m} \mathrm{K})$ ), extruded polystyrene (thermal conductivity $0.032 \mathrm{~W} /(\mathrm{m} \mathrm{K})$ ), and polyurethane (thermal conductivity $0.023 \mathrm{~W} /(\mathrm{m} \mathrm{K})$ ). The study followed a from cradle to gate approach (from façade construction materials production up to installation to the building) and showed that stone wool is the insulation material that contributes most to the environmental impacts examined. The second most impactful material is expanded polystyrene. Extruded polystyrene and polyurethane have similar results in almost all the categories investigated, while glass wool is the least impactful insulation material.

The main conclusions of the LCA results obtained by Llantoy et al. [16] and SierraPérez et al. [17] are similar. 
Beccali et al. [18] applied the LCA methodology to evaluate the life cycle energy and environmental benefits due to the following retrofit/renewable energy installation actions in a residential building: the installation of a photovoltaic system, of a condensing boiler, application of thermal insulation of the building envelope using expanded polystyrene (for the building façade and ground floor) and stone wool for the roof. However, the comparison of the environmental performance of expanded polystyrene and stone wool was out of the scope of the study.

According to the literature examined, few LCAs have been published on the use of renewable insulation materials [16]. Sierra-Pérez et al. [17] evaluated the life cycle impacts related to the production process of a cork insulation board and compared the environmental impacts with those associated to conventional insulation materials: stone wool, glass wool, expanded polystyrene, extruded polystyrene and polyurethane. Ardente et al. [19] applied LCA with the aim to assess the energy and environmental benefits and drawbacks associated with the use of kenaf-fiber thermal insulation material into residential buildings and compare them with the performances of various conventional insulation materials, like polyurethane, glass wool, flax rolls, stone wool, etc. Both SierraPérez et al. [17] and Ardente et al. [19] highlight that the use of natural insulation materials does not necessarily imply a reduction of the overall environmental impacts.

Considering the increasing interest in renewable biological resources in the context of the European Bioeconomy Strategy [14], deeper insight into the effective contribution of these materials towards a sustainable and circular economy is paramount. In addition, to support the building renovation wave initiative, the indication of the period of construction can provide a useful indication in defining an order of priority for interventions and in the allocation of the financial resources.

Recently, Gulotta et al. [20] assessed the energy and environmental impacts related to the reduction of the thermal transmittance of the EU28 building stock (including buildings realized before 1945 up to 2010) through the employment of four different insulation materials: wood board, cork slab, cellulose fibers, and stone wool. In addition, they compared the renovated building stock with the no-renovated option. The study followed a cradle to grave approach with a dynamic simulation of the building operation phase. The authors reported aggregated environmental results for the EU context and for different retrofit solutions with no individual focus on the role of the insulation.

Concerning the literature examined, the main contributions of this paper are:

- the assessment and the hot-spots analysis of the potential energy and environmental impacts of the installation of a conventional insulation material, such as stone wool, and a bio-based insulation material, cellulose fibers as retrofit intervention in residential buildings;

- the assessment of the net energy and environmental impacts and benefits due to retrofitted buildings, representative of the Italian context, characterized by different construction periods, compared with the non-retrofitted ones, assuming a from cradleto-grave perspective.

\section{Materials and Methods}

The methodological approach integrates a dynamic bottom-up approach for building simulation and the LCA for the assessment of the environmental impacts [20].

\subsection{Case Study}

The building types under investigation are urban residential multi-family houses (MHFs) in Italy and representative of three construction periods: 1945-1969, 1970-1989, and 1990-2010. About 93\% of the Italian residential houses, both MFHs and single-family houses (SFH), are built before 2010, the year of the first EPBD Directive [21], thus it can be safe to assume that the overall building stock in Italy has a high energy saving potential [20].

The MFH building model consists of a four-storey building with four flats per elevation (16 in total). Each flat has $90 \mathrm{~m}^{2}$ of usable area and $2.70 \mathrm{~m}$ story height. It is 
assumed based on a statistical analysis that MFH accommodates 32 occupants in total (2 for each apartment) [20].

The buildings examined have a reinforced concrete frame, masonry brick with an air wall cavity between two layers of gypsum sand plaster envelope, including reinforced concrete floor and roof. In addition, the MFHs built in 1990-2010 include $2 \mathrm{~cm}$ of insulation material in the vertical envelope. The $U$ values of the walls are $1.76 \mathrm{~W} /\left(\mathrm{m}^{2} \mathrm{~K}\right), 1.47 \mathrm{~W} /\left(\mathrm{m}^{2} \mathrm{~K}\right)$, and $0.81 \mathrm{~W} /\left(\mathrm{m}^{2} \mathrm{~K}\right)$ respectively for the 1945-1969, 1970-1989, and 1990-2010 construction periods, respectively [22].

Figure 1 illustrates the breakdown of the Italian residential building stock in 2010 by type of dwelling (MFH and SFH) and by degree of urbanization of the urban areas. In detail, urban areas are classified into three types: (1) Cities (densely populated), (2) Towns and suburbs (intermediate density) and (3) Rural areas (thinly populated) (https://ec. europa.eu/eurostat/web/ degree-of-urbanisation, accessed on 29 May 2021). In Italy, MFH is the most widespread type of building especially in city areas. In 2010, MFHs represented about $74 \%$ of the residential building stock, of which $44.8 \%$ in city, $22.5 \%$ in town and $6.4 \%$ in rural area.

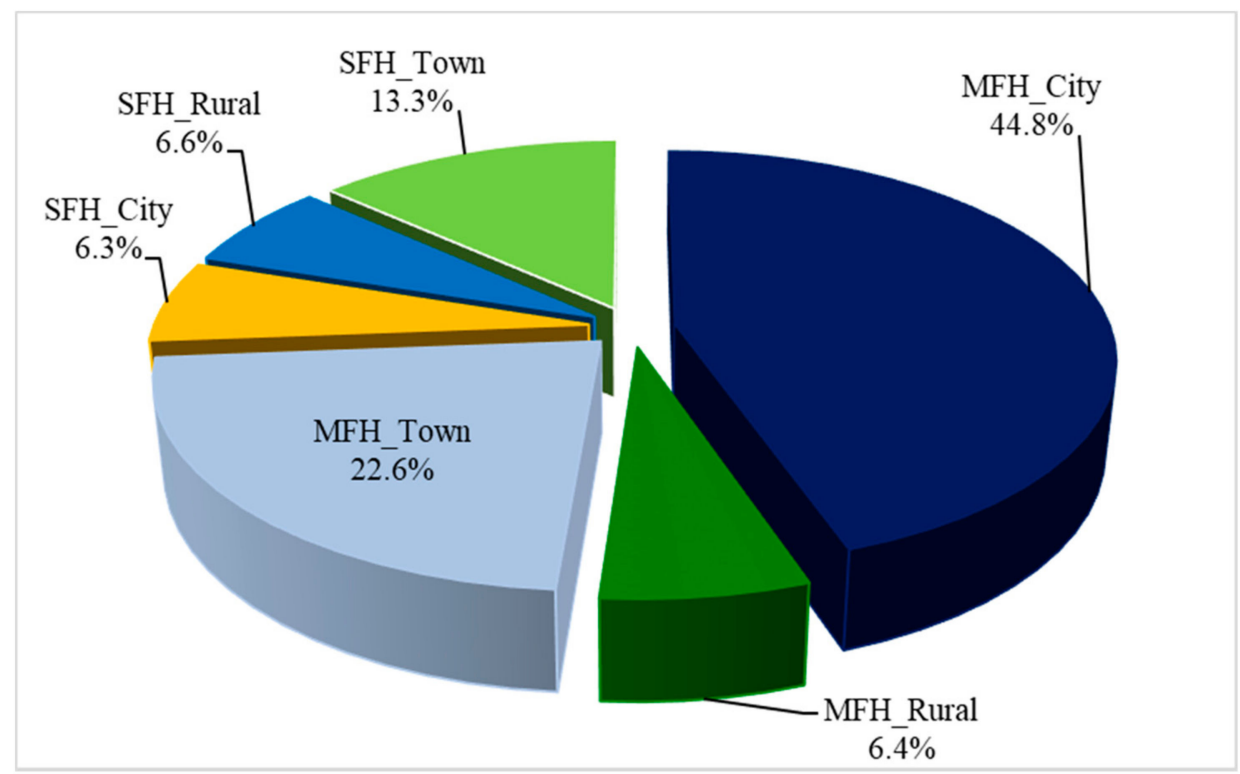

Figure 1. Breakdown of the Italian residential building stock in 2010 (Own elaboration from Eurostat Database [23] and ODYSSEE-MURE Project: https:/ / www.odyssee-mure.eu/publications/efficiency-trends-policies-profiles/italy-italian. html, accessed on 29 May 2021).

\subsection{Life Cycle Assessment}

LCA is applied according to the international ISO14040 and ISO14044 [12,13] standards and to EN15978: 2011 and EN15804: 2019 on sustainability of construction works [24,25].

\subsubsection{Goal and Scope Definition}

The goal of the study is to assess the potential life cycle energy and environmental impacts and benefits of a building envelope retrofit solution consisting of the installation of a thermal insulation material in the vertical envelope of a MFH apartment.

This objective can be further clarified as in the following:

1. to assess the potential impacts related to the retrofit actions (module B5 according to standards EN15978: 2011 and EN15804: 2019) consisting of the installation of a thermal insulation material in the vertical envelope in residential buildings characterized by different construction periods and to identify the processes responsible for the largest contribution to the impacts. The analysis is carried out following a life cycle approach; 
2. to compare the life cycle energy and environmental impacts related to the installation of two different thermal insulation materials. In detail, the following scenarios are investigated:

a. conventional insulation material: stone wool (Stone wool Scenario-SwS);

b. bio-based insulation material: cellulose fibers (Cellulose fibers Scenario-CfS).

3. to assess the net potential energy and environmental benefits obtained in retrofitted buildings (RBS), characterized by different construction periods, compared with the non-retrofitted ones (baseline building-BBS).

In compliance with the goals of the study, two functional units (FUs) are considered in the LCA:

- $\quad F U$ for building envelope retrofit assessment- $\mathrm{FU}_{\mathrm{R}}$. According to the Product Environmental Footprint Category Rules (PEFCRs) for thermal insulation, the $F U_{R}$ is defined as $1 \mathrm{~m}^{2}$ of vertical envelope, with an insulation thickness that allows the reaching of a $\mathrm{U}=0.49 \mathrm{~W} /\left(\mathrm{m}^{2} \mathrm{~K}\right)$, with an assumed life span equal to 30 years;

- $\quad \mathrm{FU}$ for life cycle energy saving assessment- $-\mathrm{FU}_{\mathrm{ES}}$. The $\mathrm{FU}_{\mathrm{ES}}$ is defined as $1 \mathrm{~m}^{2}$ of walkable floor per year. This FU is common in LCA studies in the construction sector [16]. The reference study period is assumed equal to the average replacement period assumed for thermal insulation (30 years).

Figure 2 illustrates the processes considered for the retrofit action (module B5). The system boundaries for $\mathrm{FU}_{\mathrm{R}}$ (module B5) defined according to the standard EN15978: 2011 include:

- production of the thermal insulation material and of the other opaque envelope materials that need to be replaced during the retrofit action;

- material transportation from production site to the building site;

- end-of-life (EoL) treatment of the retrofit-related wastes;

- waste materials transportation from the building site to the end-of-life treatment site.

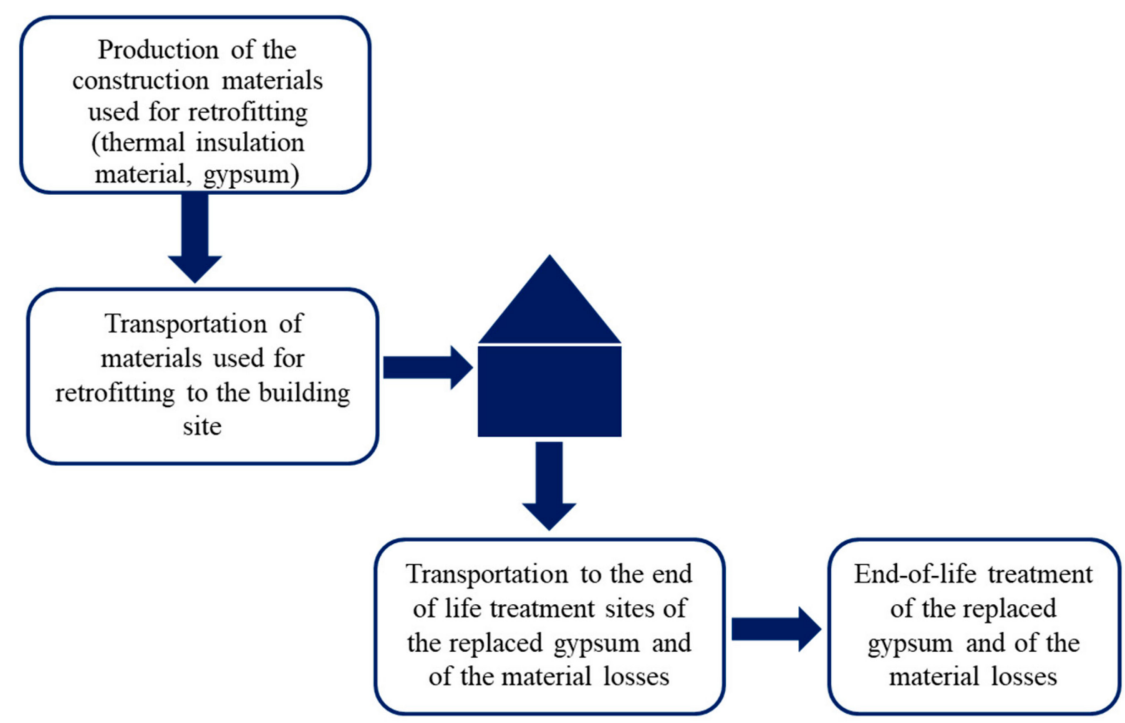

Figure 2. System boundary for $\mathrm{FU}_{\mathrm{R}}-$ retrofit action.

According to the goals of the LCA, to assess the potential energy and environmental benefits $\left(\mathrm{FU} \mathrm{ES}_{\mathrm{ES}}\right.$ ), the scope of the LCA is extended to include the energy saving related to the retrofitted building apartments compared to the baseline (i.e., non-retrofitted building apartments). The comparison between the retrofitted building apartments (retrofitted building scenario-RBS) and the baseline (baseline building scenario-BBS) is carried out considering only the life cycle modules and processes affected by the retrofit actions and excluding those that are unchanged in both RBS and BBS. Figure 3 illustrates the 
modules included in the expanded scenario for comparing BBS with RBS, according to the modularity principles followed by EN15978: 2011 and EN 15804: 2019 standards. In detail, Module B5 is accounted only for RBS. Module B6 "Operational energy use" is accounted for both RBS and BBS including only the energy uses for heating and cooling, since they are affected by the retrofit action. The transportation to the disposal site and the disposal process of the thermal insulation materials, included in module "C2-transport" and in module "C4-disposal", respectively, are accounted only for RBS.

Module A

Production stage + Construction stage

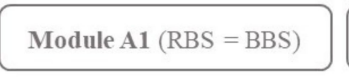

Module B1 (RBS = BBS)

Module B6 (RBS $\neq$ BBS) Energy uses affected by the retrofit intervention:

-Energy uses for cooling Energy uses for heating

Module C1 $(\mathrm{RBS}=\mathrm{BBS})$
Module A2 (RBS = BBS)

$$
\text { Module A3 (RBS = BBS) }
$$

Module B

Use stage

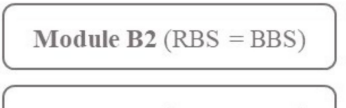

Module B7 $(\mathrm{RBS}=\mathrm{BBS})$

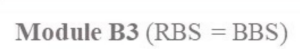

Module B3 $($ RBS $=$ BBS

Module B4 (RBS = BBS)
Module C

End-of-life stage

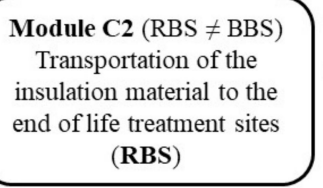

Module A5 $(\mathrm{RBS}=\mathrm{BBS})$ Module B5 (RBS $\neq$ BBS)
(RBS) Module B5 (RBS $\neq$ BBS)
(RBS)

Module A4 (RBS = BBS)

Figure 3. System boundary for $\mathrm{FU}_{\mathrm{ES}}-\mathrm{RBS}$ versus BBS.

The assessment of the environmental impacts is carried out by estimating the contribution of the product system to the main and additional environmental categories recommended by the UNI EN15804:2019 standard, except for the category "depletion of abiotic resources-fossil fuels". The energy impact assessment is carried out estimating the embodied energy considering both the contribution of non-renewable (fossil) and renewable primary energy.

The energy and environmental impacts are assessed using the following methods:

- Cumulative energy demand (CED), for the calculation of the embodied energy divided into renewable and non-renewable primary energy [26];

- EN15804 + A2 Method V1.00 for the calculation of environmental impacts, based on the EF 3.0 method developed by Fazio et al. [27].

The LCA model is implemented in SimaPro software [28].

In Table 1 the energy and environmental impact categories used in the study are listed. 
Table 1. Selected energy and environmental impact categories.

\begin{tabular}{|c|c|c|}
\hline Impact Category & Unit & Acronym \\
\hline Embodied energy & MJ & $\mathrm{EE}$ \\
\hline Embodied energy, non-renewable & MJ & $\mathrm{EE}_{\mathrm{nr}}$ \\
\hline Embodied energy, renewable & MJ & $\mathrm{EE}_{\mathrm{r}}$ \\
\hline Climate change-—total & $\mathrm{kg} \mathrm{CO}_{2 \mathrm{eq}}$ & GWP \\
\hline Climate change-fossil & $\mathrm{kgCO}_{2 \mathrm{eq}}$ & $\mathrm{GWP}_{\mathrm{f}}$ \\
\hline Climate change-biogenic & $\mathrm{kg} \mathrm{CO} 2 \mathrm{eq}$ & $\mathrm{GWP}_{\mathrm{b}}$ \\
\hline $\begin{array}{c}\text { Climate change - land use and land use } \\
\text { change }\end{array}$ & $\mathrm{kg} \mathrm{CO} 2 \mathrm{eq}$ & $\mathrm{GWP}_{\text {LULUC }}$ \\
\hline Ozone depletion & $\mathrm{kg} \mathrm{CFC}-11_{\mathrm{eq}}$ & ODP \\
\hline Acidification & $\mathrm{mol} \mathrm{H}^{+}$eq & $\mathrm{AP}$ \\
\hline Eutrophication aquatic freshwater & $\mathrm{kg} \mathrm{PO} 4 \mathrm{eq}$ & $\mathrm{EP}_{\mathrm{FW}}$ \\
\hline Eutrophication aquatic marine & $\mathrm{kg} \mathrm{Neq}$ & $\mathrm{EP}_{\mathrm{M}}$ \\
\hline Eutrophication terrestrial & molc $\mathrm{N}_{\mathrm{eq}}$ & $\mathrm{EP}_{\mathrm{T}}$ \\
\hline Photochemical ozone formation & $\mathrm{kg} \mathrm{NMVOC}$ eq & POF \\
\hline $\begin{array}{c}\text { Depletion of abiotic resources-material } \\
\text { and metals }\end{array}$ & $\mathrm{kg} \mathrm{Sb} b_{\mathrm{eq}}$ & $\mathrm{ADP}_{\mathrm{m} \& \mathrm{~m}}$ \\
\hline Water use & $\mathrm{m}^{3}$ world eq. deprived & WU \\
\hline Particulate matter emissions & Disease incidence & PM \\
\hline Ionizing radiation-human health & $\mathrm{kBq} \mathrm{U}^{235} \mathrm{eq}$ & IR \\
\hline Eco-toxicity (freshwater) & CTUe & $\mathrm{E}_{\mathrm{FW}}$ \\
\hline Human toxicity-non-cancer effects & $\mathrm{CTU}_{\mathrm{h}}$ & HT-nce \\
\hline Human toxicity—cancer effects & $\mathrm{CTU}_{\mathrm{h}}$ & HT-ce \\
\hline Land use related impacts/soil quality & - & LU \\
\hline
\end{tabular}

In addition, to get a more effective description of the energy and environmental performances of the retrofit action and an easy comparison of the two alternatives, the energy and environmental impacts were complemented by the impact payback time $\left(I_{P B T}\right)$ indices. The $\mathrm{I}_{\mathrm{PBT}}$ of a building retrofit action is the time needed to generate as much energy (valued as primary) and environmental impacts as those caused during all the life cycle phases of the retrofit action.

The $I_{P B T}$ are calculated through Equation (1)

$$
I_{P B T, n}=\frac{I_{n}}{A I_{n}}
$$

where $I_{n}$ is the life cycle impact on the energy or environmental impact category $n$ (unit); $A I_{n}$ is the yearly avoided impact on the energy or environmental impact category $n$ after retrofit (unit/year); $n$ is the number of energy and environmental impact categories investigated.

\subsubsection{Life Cycle Inventory}

The retrofit is based on the application of thermal insulation in the external walls. This action allows to reduce the $U$ values of the buildings examined from the original values reported in Section 2 to $0.49 \mathrm{~W} /\left(\mathrm{m}^{2} \mathrm{~K}\right)$. This $\mathrm{U}$ value refers to the average transmittance values for MFHs in warm climatic zone calculated in Gulotta et al. [20]. The average U calculation method accounts for the different thermal transmittance levels identified for the nZEB concept implementation in EU Member States national legislation on buildings [29]. For both CfS and SwS, the thickness of thermal insulation material required to achieve the target value is calculated accounting for the thermal characteristics of the insulation materials. The thermal conductivity and density of materials are respectively $0.039 \mathrm{~W} /(\mathrm{m} \mathrm{K})$ and $60 \mathrm{~kg} / \mathrm{m}^{3}$ for cellulose fibers and $0.040 \mathrm{~W} /(\mathrm{m} \mathrm{K})$ and $50 \mathrm{~kg} / \mathrm{m}^{3}$ for stone wool [30].

Concerning the retrofit intervention (B5) modeling, the amount of thermal insulation materials required in both CfS and SwS is calculated, based on the U value in the BBS and the $\mathrm{U}$ value target $\left(0.49 \mathrm{~W} /\left(\mathrm{m}^{2} \mathrm{~K}\right)\right)$ to achieve in RBS. The area of the insulated walls is $91.8 \mathrm{~m}^{2}$. The transportation processes are modeled assuming an average distance of 
$50 \mathrm{~km}$ for both "material production site—construction site" and "construction site-EoL treatment site" routes [31]. The EoL treatment is modeled assuming the disposal in landfill. The annual energy consumed for heating and cooling in building is calculated through the energy dynamic simulation tool EnergyPlus [32].

The model includes the setting of temperature set points, the modeling of infiltration and natural ventilation as well as the implementation of thermal loads due to the presence of people, equipment, and appliances [20]. The energy mixes for both cooling and heating energy production are inferred from Mantzos et al. [33].

The life cycle inventory list of materials and processes is shown in Table 2, while Table 3 lists the life cycle inventory datasets selected for modeling the background processes of the product system examined. These datasets are inferred from the Ecoinvent 3.6 database [34]. The recycled content, or cut-off, approach is used to compile the life cycle inventory (LCI). In the cut-off approach the impacts of multi-output processes are allocated based on the allocation factors estimated for the specific system model, e.g., on physical relations based on exergy or mass content or economic relation [34].

Table 2. Inventory list of materials and processes used for life cycle phases modeling (91.8 $\mathrm{m}^{2}$ of thermal insulated walls).

\begin{tabular}{|c|c|c|c|c|c|c|}
\hline \multirow{2}{*}{ Life Cycle Phases } & \multicolumn{3}{|c|}{ Cellulose Fibers Scenario } & \multicolumn{3}{|c|}{ Stone Wool Scenario } \\
\hline & 1945-1969 & 1970-1989 & 1990-2010 & 1945-1969 & 1970-1989 & 1990-2010 \\
\hline \multicolumn{7}{|l|}{ Module B5 } \\
\hline Insulation material (kg) & 326.51 & 297.87 & 177.58 & 276.87 & 262.55 & 152.76 \\
\hline Gypsum plasterboard (kg) & 2214.95 & 2214.95 & 2214.95 & 2214.95 & 2214.95 & 2214.95 \\
\hline Material loss-insulation material (kg) & 12.56 & 11.46 & 6.83 & 10.65 & 10.10 & 5.88 \\
\hline $\begin{array}{c}\text { Material loss-gypsum } \\
\text { material }(\mathrm{kg})\end{array}$ & 85.19 & 85.19 & 85.19 & 85.19 & 85.19 & 85.19 \\
\hline $\begin{array}{l}\text { Transportation to the } \\
\text { building site (tkm) }\end{array}$ & 127.07 & 125.64 & 119.63 & 124.59 & 123.87 & 118.89 \\
\hline $\begin{array}{c}\text { Replaced material-gypsum plasterboard to EoL } \\
\text { treatment }(\mathrm{kg})\end{array}$ & 2129.76 & 2129.76 & 2129.76 & 2129.76 & 2129.76 & 2129.76 \\
\hline $\begin{array}{l}\text { Material losses to EoL } \\
\text { treatment }(\mathrm{kg})\end{array}$ & 97.75 & 96.65 & 92.02 & 95.84 & 95.29 & 91.07 \\
\hline $\begin{array}{l}\text { Transportation of the } \\
\text { replaced material to the EoL treatment site }(\mathrm{tkm})\end{array}$ & 106.49 & 106.49 & 106.49 & 106.49 & 106.49 & 106.49 \\
\hline $\begin{array}{l}\text { Transportation of the } \\
\text { material losses to the EoL treatment site }(\mathrm{tkm})\end{array}$ & 4.89 & 4.83 & 4.60 & 4.79 & 4.76 & 4.55 \\
\hline \multicolumn{7}{|l|}{ Module B6 } \\
\hline Heating_-before retrofit (kWh/year) & 3853.11 & 3416.60 & 1781.41 & 3853.11 & 3416.60 & 1781.41 \\
\hline Cooling_-before retrofit (kWh/year) & 705.53 & 586.02 & 820.22 & 705.53 & 586.02 & 820.22 \\
\hline Heating—after retrofit (kWh/year) & 2295.73 & 2225.53 & 1382.09 & 2295.73 & 2225.53 & 1382.09 \\
\hline Cooling-after retrofit (kWh/year) & 734.25 & 601.40 & 852.72 & 734.25 & 601.40 & 852.72 \\
\hline $\begin{array}{c}\text { Module C } \\
\text { Transportation of the } \\
\text { insulation material to the EoL site }(\mathrm{tkm})\end{array}$ & 15.70 & 14.32 & 8.54 & 13.31 & 12.62 & 7.34 \\
\hline Insulation material to the EoL treatment $(\mathrm{kg})$ & 313.96 & 286.42 & 170.75 & 266.22 & 252.45 & 146.88 \\
\hline
\end{tabular}


Table 3. Life cycle inventory datasets selected for life cycle phases modeling.

\begin{tabular}{|c|c|}
\hline Module B5 & Ecoinvent 3.6 Dataset Used for LCI Modeling [34] \\
\hline Cellulose fibers production & Cellulose fiber, inclusive blowing in production \\
\hline Stone wool production & Stone wool production \\
\hline Gypsum plasterboard production & Gypsum plasterboard production \\
\hline Transportation to the building site & Transport, freight, lorry 16-32 metric ton, EURO6 \\
\hline Replaced material-transportation to the EoL treatment site & Transport, freight, lorry 16-32 metric ton, EURO6 \\
\hline Cellulose fibers production loss EoL treatment & Treatment of inert waste, inert material landfill \\
\hline Stone wool production loss EoL treatment & Treatment of waste mineral wool collection for final disposal \\
\hline Replaced material EoL treatment—gypsum plasterboard & $\begin{array}{c}\text { Treatment of waste gypsum plasterboard collection for final } \\
\text { disposal }\end{array}$ \\
\hline Replaced material—-transportation to the EoL treatment site & Transport, freight, lorry 16-32 metric ton, EURO6 \\
\hline Module B6 & Ecoinvent 3.6 Dataset Used for LCI Modeling \\
\hline Solids & Heat production, hard coal coke, stove $5-15 \mathrm{~kW}$ \\
\hline Liquefied petroleum gas & Heat production, natural gas, at boiler modulating $<100 \mathrm{~kW}$ \\
\hline Gas/diesel oil incl. biofuels & $\begin{array}{l}\text { Heat production, light fuel oil, at boiler } 10 \mathrm{~kW} \text { condensing, } \\
\text { non-modulating }\end{array}$ \\
\hline Gases incl. biogas & Heat production, natural gas, at boiler modulating $<100 \mathrm{~kW}$ \\
\hline Biomass and wastes & Heat production, mixed logs, at wood heater $6 \mathrm{~kW}$ \\
\hline Derived heat & Heat, district or industrial, other than natural gas \\
\hline Advanced electric heating & Heat, air-water heat pump $10 \mathrm{~kW}$ \\
\hline Conventional electric heating & Electricity, low voltage $\{\mathrm{IT}\}$ \\
\hline Air conditioner (cooling) & Electricity, low voltage $\{\mathrm{IT}\}$ \\
\hline Module C & Ecoinvent 3.6 Dataset Used for LCI Modeling \\
\hline Transportation of the insulation material to the EoL site & Transport, freight, lorry 16-32 metric ton, EURO6 \\
\hline EoL treatment—cellulose fiber & Treatment of inert waste, inert material landfill \\
\hline EoL treatment-stone wool & Treatment of waste mineral wool collection for final disposal \\
\hline
\end{tabular}

\section{Results and Discussion}

\subsection{Life Cycle Impact Assessment and Interpretation: The Retrofit Action (Module B5)}

Table 4 shows the life cycle impact assessment (LCIA) results caused by the retrofit intervention on the vertical envelope of Italian residential apartment buildings for both CfS and SwS. The comparison of the energy and environmental impacts associated with the SwS and CfS highlights that the CfS performs better than the SwS in almost all the categories examined. The exceptions are renewable embodied energy $\left(\mathrm{EE}_{\mathrm{R}}\right)$, land use related impacts / soil quality (LU), water use (WU), depletion of abiotic resources-material and metals $\left(\mathrm{ADP}_{\mathrm{m} \& \mathrm{~m}}\right)$, climate change-biogenic $\left(\mathrm{GWP}_{\mathrm{b}}\right)$ and climate change-land use and land use change $\left(\mathrm{GWP}_{\text {LULUC }}\right)$, in which the percentage variation of the contribution related to the CfS ranges from a minimum value equal to about $4 \%$ for WU to a maximum value of about $154 \%$ for $\mathrm{ADP}_{\mathrm{m} \& \mathrm{~m}}$. A more thorough impact analysis shows that:

- $\quad$ in $\mathrm{EE}_{\mathrm{R}}, \mathrm{LU}, \mathrm{GWP}_{\mathrm{b}}$, and $\mathrm{GWP}_{\mathrm{LULUC}}$ the highest contribution is due to the paper used in the production process of the cellulose fibers insulation material;

- $\quad$ in $\mathrm{ADP}_{\mathrm{m} \& \mathrm{~m}}$, boric acid used to enhance fire retarding properties of the cellulose fibers is responsible for the highest contribution.

Concerning the WU impact category, the highest impact of the CfS is due to high amounts of insulation materials required to achieve the U-value target respect to the SwS. These results highlight that the bio-based insulation material allows to improve the environmental performance of the retrofit intervention examined in a wide range of impact categories in comparison with a conventional insulation material. However, further innovations are required to achieve improvements in the whole set of environmental impacts categories. The use of cellulose fibers for buildings energy retrofit allows to reduce the impact on climate change (GWP) by about 20\% for 1970-1989 and 1990-2010 construction periods and by $12 \%$ for 1990-2010 construction period. Then, the use of cellulose fibers as insulation material can provide a positive contribution to meet climate 
change goals. However, they have a higher impact in terms of resources consumption compared to stone wool insulation material. In detail, the impacts on $\mathrm{ADP}_{\mathrm{m} \& \mathrm{~m}}$ increase by about $150 \%$ for $1970-1989$ and 1990-2010 construction periods and by $95 \%$ for $1990-2010$ construction period in CfS compared to SwS. Resources' consumption is a key indicator of the circular economy transition, then this is a crucial area of improvement for bio-based insulation material. Boric acid is the compound responsible for the largest contribution to $\mathrm{ADP}_{\mathrm{m} \& \mathrm{~m}}$, it is mainly produced from borate that is included in the 2020 list of Critical Raw Materials for the EU [35]. Then, the use of alternative flame retardant compounds, such as ammonium-based formulation [36], might be a more sustainable option in terms of resource depletion.

Table 4. LCIA—retrofit action—cellulose fibers (Cf) and stone wool (Sw) scenarios-FUR: $1 \mathrm{~m}^{2}$ of vertical envelope.

\begin{tabular}{|c|c|c|c|c|c|c|}
\hline Impact Category & $\begin{array}{c}\text { CfS } \\
1945-1969\end{array}$ & $\begin{array}{c}\text { CfS } \\
1970-1989\end{array}$ & $\begin{array}{c}\text { CfS } \\
1990-2010\end{array}$ & $\begin{array}{c}\text { SwS } \\
1945-1969\end{array}$ & $\begin{array}{c}\text { SwS } \\
1970-1989\end{array}$ & $\begin{array}{c}\text { SwS } \\
1990-2010\end{array}$ \\
\hline $\mathrm{EE}(\mathrm{MJ})$ & 4.52 & 4.44 & 4.03 & 4.98 & 4.86 & 4.28 \\
\hline $\mathrm{EE}_{\mathrm{nr}}(\mathrm{MJ})$ & 3.31 & 3.25 & 2.97 & 3.98 & 3.87 & 3.34 \\
\hline $\mathrm{EE}_{\mathrm{r}}(\mathrm{MJ})$ & 1.21 & 1.18 & 1.05 & 1.00 & $9.92 \times 10^{-1}$ & $9.41 \times 10^{-1}$ \\
\hline $\mathrm{GWP}\left(\mathrm{kg} \mathrm{CO} \mathrm{Coq}_{2}\right)$ & $1.85 \times 10^{-1}$ & $1.82 \times 10^{-1}$ & $1.68 \times 10^{-1}$ & $2.56 \times 10^{-1}$ & $2.48 \times 10^{-1}$ & $2.07 \times 10^{-1}$ \\
\hline $\begin{array}{c}\mathrm{ODP}(\mathrm{kg} \\
\left.\mathrm{CFC}-11_{\mathrm{eq}}\right)\end{array}$ & $2.50 \times 10^{-8}$ & $2.46 \times 10^{-8}$ & $2.28 \times 10^{-8}$ & $2.73 \times 10^{-8}$ & $2.67 \times 10^{-8}$ & $2.40 \times 10^{-8}$ \\
\hline $\operatorname{IR}\left(\mathrm{kBq} \mathrm{U}^{235} \mathrm{eq}\right)$ & $3.50 \times 10^{-2}$ & $3.45 \times 10^{-2}$ & $3.21 \times 10^{-2}$ & $3.78 \times 10^{-2}$ & $3.71 \times 10^{-2}$ & $3.36 \times 10^{-2}$ \\
\hline $\begin{array}{c}\text { POF }(\mathrm{kg} \\
\left.\text { NMVOC }_{\text {eq }}\right)\end{array}$ & $1.43 \times 10^{-3}$ & $1.41 \times 10^{-3}$ & $1.31 \times 10^{-3}$ & $1.71 \times 10^{-3}$ & $1.67 \times 10^{-3}$ & $1.46 \times 10^{-3}$ \\
\hline $\begin{array}{l}\text { PM (Disease } \\
\text { incidence) }\end{array}$ & $2.66 \times 10^{-8}$ & $2.61 \times 10^{-8}$ & $2.40 \times 10^{-8}$ & $2.67 \times 10^{-8}$ & $2.62 \times 10^{-8}$ & $2.41 \times 10^{-8}$ \\
\hline $\mathrm{HT}-$ nce $\left(\mathrm{CTU}_{\mathrm{h}}\right)$ & $3.67 \times 10^{-9}$ & $3.57 \times 10^{-9}$ & $3.07 \times 10^{-9}$ & $3.70 \times 10^{-9}$ & $3.59 \times 10^{-9}$ & $3.08 \times 10^{-9}$ \\
\hline $\mathrm{HT}-$ ce $\left(\mathrm{CTU}_{\mathrm{h}}\right)$ & $1.30 \times 10^{-10}$ & $1.25 \times 10^{-10}$ & $1.05 \times 10^{-10}$ & $5.71 \times 10^{-10}$ & $5.32 \times 10^{-10}$ & $3.48 \times 10^{-10}$ \\
\hline $\mathrm{AP}\left(\mathrm{mol} \mathrm{H}_{\mathrm{eq}}^{+}\right)$ & $9.23 \times 10^{-3}$ & $9.20 \times 10^{-3}$ & $9.02 \times 10^{-3}$ & $9.87 \times 10^{-3}$ & $9.78 \times 10^{-3}$ & $9.38 \times 10^{-3}$ \\
\hline $\mathrm{EP}_{\mathrm{FW}}\left(\mathrm{kg} \mathrm{PO}_{4 \mathrm{eq}}\right)$ & $6.61 \times 10^{-5}$ & $6.45 \times 10^{-5}$ & $5.66 \times 10^{-5}$ & $8.16 \times 10^{-5}$ & $7.87 \times 10^{-5}$ & $6.52 \times 10^{-5}$ \\
\hline $\mathrm{EP}_{\mathrm{M}}\left(\mathrm{kg} \mathrm{N} \mathrm{N}_{\mathrm{eq}}\right)$ & $3.46 \times 10^{-4}$ & $3.40 \times 10^{-4}$ & $3.08 \times 10^{-4}$ & $3.63 \times 10^{-4}$ & $3.55 \times 10^{-4}$ & $3.17 \times 10^{-4}$ \\
\hline $\mathrm{EP}_{\mathrm{T}}\left(\mathrm{mol} \mathrm{N} \mathrm{N}_{\mathrm{eq}}\right)$ & $3.66 \times 10^{-3}$ & $3.59 \times 10^{-3}$ & $3.24 \times 10^{-3}$ & $4.57 \times 10^{-3}$ & $4.43 \times 10^{-3}$ & $3.74 \times 10^{-3}$ \\
\hline $\mathrm{E}_{\mathrm{FW}}(\mathrm{CTUe})^{1}$ & 8.89 & 8.73 & 7.95 & 9.25 & 9.06 & 8.15 \\
\hline LU (-) & 5.65 & 5.49 & 4.70 & 4.16 & 4.11 & 3.88 \\
\hline $\begin{array}{c}\text { WU } \\
\left(\mathrm{m}^{3} \text { world eq. Deprived }\right)\end{array}$ & $7.51 \times 10^{-2}$ & $7.32 \times 10^{-2}$ & $6.38 \times 10^{-2}$ & $7.23 \times 10^{-2}$ & $7.06 \times 10^{-2}$ & $6.23 \times 10^{-2}$ \\
\hline $\mathrm{ADP}_{\mathrm{m} \& \mathrm{~m}}\left(\mathrm{~kg} \mathrm{Sb_{eq }}\right)$ & $8.99 \times 10^{-6}$ & $8.51 \times 10^{-6}$ & $6.16 \times 10^{-6}$ & $3.54 \times 10^{-6}$ & $3.47 \times 10^{-6}$ & $3.17 \times 10^{-6}$ \\
\hline $\mathrm{GWP}_{\mathrm{f}}\left(\mathrm{kg} \mathrm{CO} \mathrm{CO}_{2 \mathrm{eq}}\right)$ & $2.09 \mathrm{E} \times 10^{-1}$ & $2.05 \times 10^{-1}$ & $1.87 \times 10^{-1}$ & $2.70 \times 10^{-1}$ & $2.61 \times 10^{-1}$ & $2.20 \times 10^{-1}$ \\
\hline $\mathrm{GWP}_{\mathrm{b}}\left(\mathrm{kg} \mathrm{CO} \mathrm{CO}_{2 \mathrm{eq}}\right)$ & $-2.44 \times 10^{-2}$ & $-2.36 \times 10^{-2}$ & $-1.96 \times 10^{-2}$ & $-1.40 \times 10^{-2}$ & $-1.40 \times 10^{-2}$ & $-1.40 \times 10^{-2}$ \\
\hline
\end{tabular}

Figures 4 and 5 illustrate the contribution analysis results of the different life cycle phases to the module B5 impacts in the case of buildings constructed between 1945 and 1969 in CfS and SwS, respectively. The contribution analysis results for 1970-1989 and 1990-2010 construction periods are reported in Appendix A (Figures A1-A4).

The analysis highlights that the gypsum plasterboard production contributes significantly to a wide range of impact categories in both CfS and SwS, for all the construction periods examined. In detail, it contributes to more than $45 \%$ in all the impact categories investigated, except for photochemical ozone formation (POF), particulate matter emissions (PM), human toxicity-non-cancer effects (HT-nce), human toxicity-cancer effects (HT-ce), $\mathrm{AP}$, and $\mathrm{ADP}_{\mathrm{m} \& \mathrm{~m}}$. In addition, the EoL treatment of gypsum plasterboard is responsible for the largest contribution on acidification (AP) (about 80\%), POF and PM (about 40\%). In the CfS, gypsum plasterboard life cycle (production and EoL treatment) is responsible for a contribution to the B5 impacts ranging from a minimum value of $26 \%$ (for ADP $\mathrm{m} \& \mathrm{~m}$, 1945-1969 construction period) up to 93\% (for AP, 1990-2010 construction period). In the SwS, gypsum plasterboard is responsible for a contribution to the B5 impacts ranging from a minimum value of $12 \%$ (for HT-ce and 1945-1969 construction period) up to $90 \%$ (for AP and 1990-2010 construction period). 


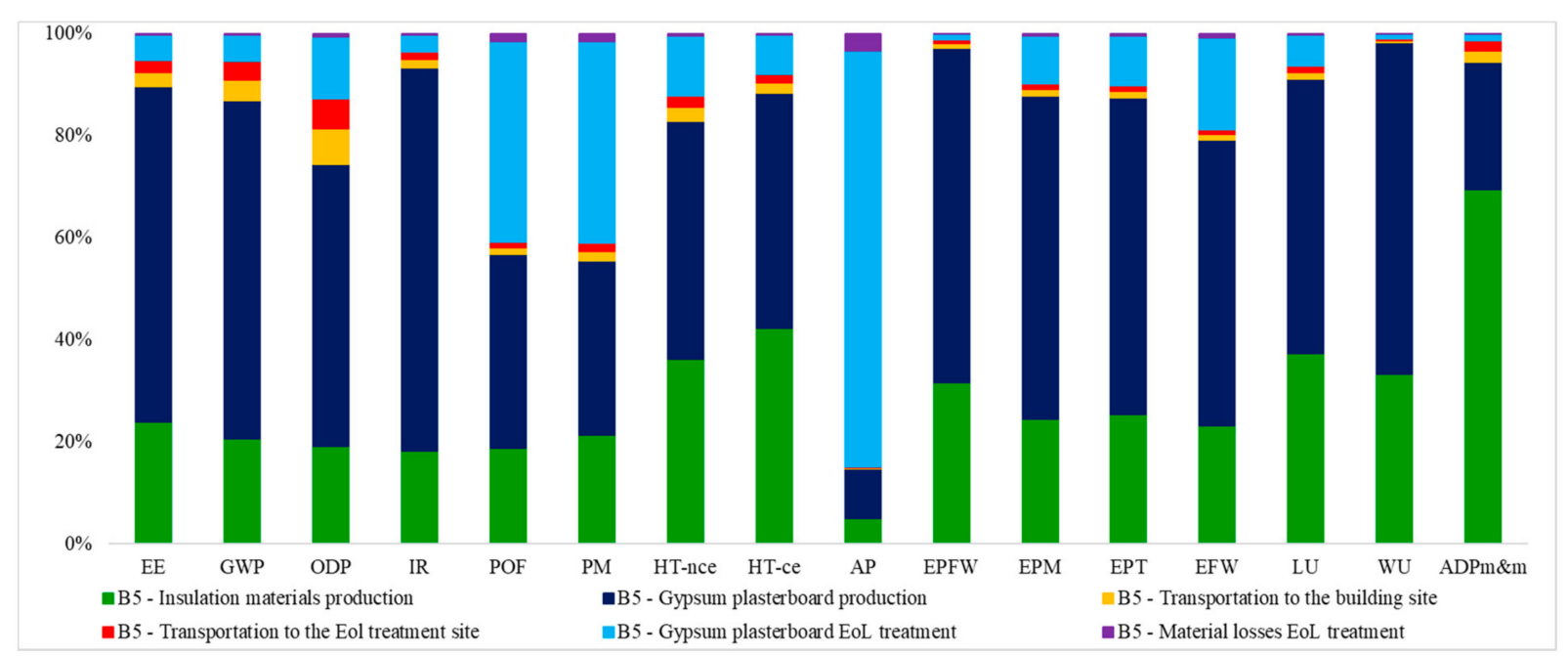

Figure 4. Contribution of the different life cycle phases to the B5 module impacts-CfS (1945-1969).

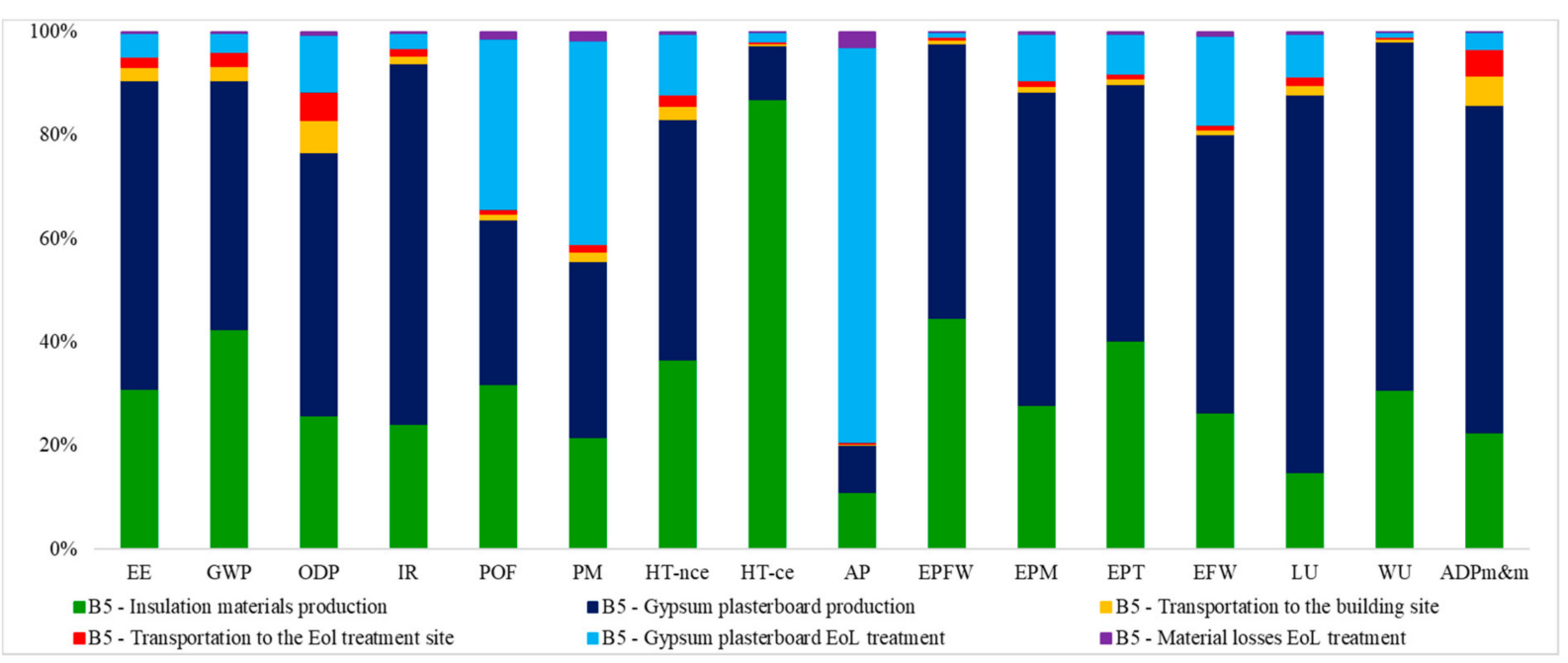

Figure 5. Contribution of the different life cycle phases to the B5 module impacts-SwS (1945-1969).

Concerning the insulation materials, the contribution of the cellulose fibers production to the B5 module impacts is significant in the following impact categories:

- $\quad \mathrm{ADP}_{\mathrm{m} \& \mathrm{~m}}$ (about 70\% for 1945-1969 and 1970-1989 construction periods, and 56\% for 1990-2010 construction period);

- HT impact categories (HT-nce: about 35\% for 1945-1969 and 1970-1989 construction periods and $24 \%$ for $1990-2010$ construction period; HT-ce: about $40 \%$ for $1945-1969$ and 1970-1989 construction periods, and 30\% for 1990-2010 construction period);

- LU (about 37\% for 1945-1969 and 1970-1989 construction periods, and 25\% for 1990-2010 construction period).

The contribution of stone wool production to the B5 module impacts is relevant for $\mathrm{HT}$-ce, eutrophication aquatic freshwater $\mathrm{EP}_{\mathrm{FW}}$, eutrophication terrestrial $\left(\mathrm{EP}_{\mathrm{T}}\right)$, and GWP. In detail, it contributes to more than $80 \%$ to HT-ce in all the construction periods examined. A deeper analysis highlights that the coke used in the production process is responsible for the largest contribution. Concerning $\mathrm{EP}_{\mathrm{FW}}$ and $\mathrm{EP}_{\mathrm{T}}$ impact categories the contribution is about $40 \%$ for $1945-1969$ and $1970-1989$ construction periods and $30 \%$ for $1990-2010$ construction period. Finally, stone wool production accounts for about $40 \%$ of the GWP for 1945-1969 and 1970-1989 construction periods and 30\% for 1990-2010 construction period. In CfS, transportation processes contribute less than $6 \%$ in almost all the impact categories, except for ozone depletion (ODP) and GWP, in which they account for about $14 \%$ and $8 \%$, 
respectively. The highest contribution to GWP is given by the direct emissions related to the transportation process, while the largest contribution to ODP is related to the production process of the diesel consumed by lorry. In SwS, the transportation processes contribute for less than $6 \%$ in almost all the impact categories, except for ODP and $\mathrm{ADP}_{\mathrm{m} \& \mathrm{~m}}$ in which they account for about $12 \%$. The process responsible for the larger contribution to $\mathrm{ADP}_{\mathrm{m} \& \mathrm{~m}}$ is associated to the lorry maintenance phase [34].

4.2. Life Cycle Impact Assessment and Interpretation: Comparison of the Retrofitted and the Non Retrofitted Building Apartments

According to goal 3 (Section 3.2.1), the scope of the LCA is extended to include the energy saving related to the retrofitted building apartment compared to the baseline building apartment. The LCIA results of the expanded system boundaries connected to the $\mathrm{FU}_{\mathrm{ES}}\left(1 \mathrm{~m}^{2}\right.$ of liveable floor per year) are reported in Tables 5 and 6 , respectively for CfS and SwS, the impacts of RBS are expressed as percentage variations respect to the impacts of BBS.

Table 5. LCIA—expanded system boundaries—cellulose fibers scenarios (FU $\mathrm{ES}_{\mathrm{S}} 1 \mathrm{~m}^{2}$ of walkable floor per year).

\begin{tabular}{|c|c|c|c|c|c|c|}
\hline \multirow[b]{2}{*}{ Impact Category } & \multicolumn{2}{|c|}{ 1945-1969 } & \multicolumn{2}{|c|}{ 1970-1989 } & \multicolumn{2}{|c|}{ 1990-2010 } \\
\hline & RBS & $\begin{array}{c}\text { (RBS- } \\
\text { BBS)/BBS }\end{array}$ & RBS & $\begin{array}{c}\text { (RBS- } \\
\text { BBS)/BBS }\end{array}$ & RBS & $\begin{array}{c}\text { (RBS- } \\
\text { BBS)/BBS }\end{array}$ \\
\hline EE (MJ) & $2.1 \times 10^{2}$ & $-28.7 \%$ & $1.9 \times 10^{2}$ & $-25.0 \%$ & $1.7 \times 10^{2}$ & $-8.9 \%$ \\
\hline $\mathrm{EE}_{\mathrm{nr}}(\mathrm{MJ})$ & $1.4 \times 10^{2}$ & $-26.4 \%$ & $1.3 \times 10^{2}$ & $-23.0 \%$ & $1.2 \times 10^{2}$ & $-7.1 \%$ \\
\hline $\mathrm{EE}_{\mathrm{r}}(\mathrm{MJ})$ & $7.1 \times 10^{1}$ & $-32.9 \%$ & $6.7 \times 10^{1}$ & $-28.5 \%$ & $5.2 \times 10^{1}$ & $-12.8 \%$ \\
\hline GWP $\left(\mathrm{kg} \mathrm{CO} \mathrm{CO}_{2 \mathrm{eq}}\right)$ & 9.8 & $-27.4 \%$ & 9.0 & $-23.9 \%$ & 8.1 & $-8.0 \%$ \\
\hline $\begin{array}{c}\mathrm{ODP}(\mathrm{kg} \\
\left.\mathrm{CFC}-11_{\mathrm{eq}}\right)\end{array}$ & $1.1 \times 10^{-6}$ & $-25.0 \%$ & $1.0 \times 10^{-6}$ & $-21.9 \%$ & $9.3 \times 10^{-7}$ & $-6.2 \%$ \\
\hline $\operatorname{IR}\left(\mathrm{kBq} \mathrm{U}^{235}{ }_{\mathrm{eq}}\right)$ & $5.7 \times 10^{-1}$ & $-4.1 \%$ & $4.9 \times 10^{-1}$ & $-2.9 \%$ & $5.9 \times 10^{-1}$ & $5.7 \%$ \\
\hline $\begin{array}{c}\text { POF }(\mathrm{kg} \\
\left.\text { NMVOC }_{\mathrm{eq}}\right)\end{array}$ & $4.1 \times 10^{-2}$ & $-32.5 \%$ & $3.9 \times 10^{-2}$ & $-27.8 \%$ & $3.0 \times 10^{-2}$ & $-11.5 \%$ \\
\hline $\begin{array}{l}\text { PM (Disease } \\
\text { incidence) }\end{array}$ & $1.2 \times 10^{-6}$ & $-37.4 \%$ & $1.2 \times 10^{-6}$ & $-32.0 \%$ & $7.8 \times 10^{-7}$ & $-17.5 \%$ \\
\hline HT-nce $\left(\mathrm{CTU}_{\mathrm{h}}\right)$ & $2.4 \times 10^{-7}$ & $-35.8 \%$ & $2.3 \times 10^{-7}$ & $-30.9 \%$ & $1.6 \times 10^{-7}$ & $-16.0 \%$ \\
\hline HT-ce $\left(\mathrm{CTU}_{\mathrm{h}}\right)$ & $2.8 \times 10^{-9}$ & $-23.7 \%$ & $2.6 \times 10^{-9}$ & $-20.3 \%$ & $2.4 \times 10^{-9}$ & $-4.6 \%$ \\
\hline $\mathrm{AP}(\mathrm{mol} \mathrm{H}+\mathrm{eq})$ & $3.8 \times 10^{-2}$ & $8.3 \%$ & $3.5 \times 10^{-2}$ & $14.0 \%$ & $3.7 \times 10^{-2}$ & $28.2 \%$ \\
\hline $\mathrm{EP}_{\mathrm{FW}}(\mathrm{kg} \mathrm{PO}-\mathrm{eq})$ & $1.3 \times 10^{-3}$ & $-3.2 \%$ & $1.1 \times 10^{-3}$ & $-2.4 \%$ & $1.3 \times 10^{-3}$ & $5.0 \%$ \\
\hline $\mathrm{EP}_{\mathrm{M}}\left(\mathrm{kg} \mathrm{N}_{\mathrm{eq}}\right)$ & $5.9 \times 10^{-3}$ & $-20.5 \%$ & $5.3 \times 10^{-3}$ & $-17.3 \%$ & $5.1 \times 10^{-3}$ & $-1.5 \%$ \\
\hline $\mathrm{EP}_{\mathrm{T}}\left(\mathrm{mol} \mathrm{N} \mathrm{N}_{\mathrm{eq}}\right)$ & $7.1 \times 10^{-2}$ & $-19.3 \%$ & $6.3 \times 10^{-2}$ & $-16.4 \%$ & $6.3 \times 10^{-2}$ & $-1.3 \%$ \\
\hline $\mathrm{E}_{\mathrm{FW}}(\mathrm{CTUe})$ & $1.7 \times 10^{2}$ & $-28.5 \%$ & $1.6 \times 10^{2}$ & $-24.1 \%$ & $1.3 \times 10^{2}$ & $-7.1 \%$ \\
\hline LU $(-)$ & $1.3 \times 10^{2}$ & $-33.0 \%$ & $1.2 \times 10^{2}$ & $-28.1 \%$ & $9.1 \times 10^{1}$ & $-12.1 \%$ \\
\hline $\begin{array}{c}\text { WU } \\
\left(\mathrm{m}^{3}{ }_{\text {world eq. Deprived }}\right)\end{array}$ & 2.2 & $4.5 \%$ & 1.8 & $4.0 \%$ & 2.4 & $6.0 \%$ \\
\hline $\mathrm{ADP}_{\mathrm{m} \& \mathrm{~m}}\left(\mathrm{~kg} \mathrm{Sb} \mathrm{eq}_{\mathrm{eq}}\right)$ & $4.8 \times 10^{-5}$ & $4.9 \%$ & $4.2 \times 10^{-5}$ & $8.1 \%$ & $4.5 \times 10^{-5}$ & $13.9 \%$ \\
\hline $\mathrm{GWP}_{\mathrm{f}}\left(\mathrm{kg} \mathrm{CO}_{2 \mathrm{eq}}\right)$ & 9.0 & $-26.8 \%$ & 8.2 & $-23.4 \%$ & 7.4 & $-7.4 \%$ \\
\hline $\mathrm{GWP}_{\mathrm{b}}\left(\mathrm{kg} \mathrm{CO} \mathrm{CO}_{2 \mathrm{eq}}\right)$ & $8.7 \times 10^{-1}$ & $-32.7 \%$ & $8.0 \times 10^{-1}$ & $-29.2 \%$ & $6.8 \times 10^{-1}$ & $-14.1 \%$ \\
\hline $\begin{array}{c}\mathrm{GWP}_{\text {LULUC }}(\mathrm{kg} \\
\left.\mathrm{CO}_{2 \mathrm{eq}}\right)\end{array}$ & $5.7 \times 10^{-3}$ & $-32.6 \%$ & $5.4 \times 10^{-3}$ & $-27.2 \%$ & $3.9 \times 10^{-3}$ & $-10.3 \%$ \\
\hline
\end{tabular}


Table 6. LCIA—expanded system boundaries—stone wool scenarios (FUES: $1 \mathrm{~m}^{2}$ of walkable floor per year).

\begin{tabular}{|c|c|c|c|c|c|c|}
\hline \multirow[b]{2}{*}{ Impact Category } & \multicolumn{2}{|c|}{ 1945-1969 } & \multicolumn{2}{|c|}{ 1970-1989 } & \multicolumn{2}{|c|}{$1990-2010$} \\
\hline & RBS & $\begin{array}{c}\text { (RBS- } \\
\text { BBS)/BBS }\end{array}$ & RBS & $\begin{array}{c}\text { (RBS- } \\
\text { BBS)/BBS }\end{array}$ & RBS & $\begin{array}{c}\text { (RBS- } \\
\text { BBS)/BBS }\end{array}$ \\
\hline $\mathrm{EE}(\mathrm{MJ})$ & $2.1 \times 10^{2}$ & $-28.5 \%$ & $1.9 \times 10^{2}$ & $-24.8 \%$ & $1.7 \times 10^{2}$ & $-8.8 \%$ \\
\hline $\mathrm{EE}_{\mathrm{nr}}(\mathrm{MJ})$ & $1.4 \times 10^{2}$ & $-26.0 \%$ & $1.3 \times 10^{2}$ & $-22.6 \%$ & $1.2 \times 10^{2}$ & $-6.8 \%$ \\
\hline $\mathrm{EE}_{\mathrm{r}}(\mathrm{MJ})$ & $7.1 \times 10^{1}$ & $-33.1 \%$ & $6.6 \times 10^{1}$ & $-28.7 \%$ & $5.2 \times 10^{1}$ & $-13.0 \%$ \\
\hline GWP $(\mathrm{kg} \mathrm{CO} 2 \mathrm{eq})$ & 9.9 & $-26.8 \%$ & 9.1 & $-23.4 \%$ & 8.1 & $-7.6 \%$ \\
\hline $\begin{array}{c}\mathrm{ODP}(\mathrm{kg} \\
\left.\mathrm{CFC}-11_{\mathrm{eq}}\right)\end{array}$ & $1.1 \times 10^{-6}$ & $-24.8 \%$ & $1.0 \times 10^{-6}$ & $-21.7 \%$ & $9.3 \times 10^{-7}$ & $-6.0 \%$ \\
\hline $\operatorname{IR}\left(\mathrm{kBq} \mathrm{U}^{235}\right.$ eq $)$ & $5.7 \times 10^{-1}$ & $-3.6 \%$ & $4.9 \times 10^{-1}$ & $-2.3 \%$ & $5.9 \times 10^{-1}$ & $6.0 \%$ \\
\hline $\begin{array}{c}\text { POF }(k g \\
\left.\text { NMVOC }_{\mathrm{eq}}\right)\end{array}$ & $4.2 \times 10^{-2}$ & $-32.0 \%$ & $3.9 \times 10^{-2}$ & $-27.3 \%$ & $3.0 \times 10^{-2}$ & $-11.0 \%$ \\
\hline $\begin{array}{l}\text { PM (Disease } \\
\text { incidence) }\end{array}$ & $1.2 \times 10^{-6}$ & $-37.4 \%$ & $1.2 \times 10^{-6}$ & $-32.0 \%$ & $7.8 \times 10^{-7}$ & $-17.5 \%$ \\
\hline HT-nce $\left(\mathrm{CTU}_{\mathrm{h}}\right)$ & $2.4 \times 10^{-7}$ & $-35.8 \%$ & $2.3 \times 10^{-7}$ & $-30.9 \%$ & $1.6 \times 10^{-7}$ & $-16.0 \%$ \\
\hline HT-ce $\left(\mathrm{CTU}_{\mathrm{h}}\right)$ & $3.3 \times 10^{-9}$ & $-11.5 \%$ & $3.0 \times 10^{-9}$ & $-7.4 \%$ & $2.6 \times 10^{-9}$ & $5.5 \%$ \\
\hline $\mathrm{AP}\left(\mathrm{mol} \mathrm{H}+{ }_{\mathrm{eq}}\right)$ & $3.9 \times 10^{-2}$ & $10.1 \%$ & $3.6 \times 10^{-2}$ & $15.9 \%$ & $3.8 \times 10^{-2}$ & $29.4 \%$ \\
\hline $\mathrm{EP}_{\mathrm{FW}}(\mathrm{kg} \mathrm{PO} 4 \mathrm{eq})$ & $1.3 \times 10^{-3}$ & $-2.0 \%$ & $1.1 \times 10^{-3}$ & $-1.1 \%$ & $1.3 \times 10^{-3}$ & $5.7 \%$ \\
\hline $\mathrm{EP}_{\mathrm{M}}\left(\mathrm{kg} \mathrm{N}_{\mathrm{eq}}\right)$ & $5.9 \times 10^{-3}$ & $-20.3 \%$ & $5.3 \times 10^{-3}$ & $-17.0 \%$ & $5.1 \times 10^{-3}$ & $-1.3 \%$ \\
\hline $\mathrm{EP}_{\mathrm{T}}(\mathrm{mol} \mathrm{N}$ eq $)$ & $7.2 \times 10^{-2}$ & $-18.2 \%$ & $6.4 \times 10^{-2}$ & $-15.3 \%$ & $6.3 \times 10^{-2}$ & $-0.5 \%$ \\
\hline $\mathrm{E}_{\mathrm{FW}}$ (CTUe) & $1.7 \times 10^{2}$ & $-28.3 \%$ & $1.6 \times 10^{2}$ & $-23.9 \%$ & $1.3 \times 10^{2}$ & $-6.9 \%$ \\
\hline LU $(-)$ & $1.3 \times 10^{2}$ & $-33.8 \%$ & $1.2 \times 10^{2}$ & $-28.9 \%$ & $9.0 \times 10^{1}$ & $-12.9 \%$ \\
\hline$\left(\mathrm{m}^{3}{ }_{\text {world eq. Deprived }}\right)$ & 2.2 & $4.4 \%$ & 1.8 & $3.9 \%$ & 2.4 & $5.9 \%$ \\
\hline $\mathrm{ADP}_{\mathrm{m} \& \mathrm{~m}}(\mathrm{~kg} \mathrm{Sb} \mathrm{eq})$ & $4.2 \times 10^{-5}$ & $-7.3 \%$ & $3.7 \times 10^{-5}$ & $-5.1 \%$ & $4.1 \times 10^{-5}$ & $6.1 \%$ \\
\hline $\mathrm{GWP}_{\mathrm{f}}(\mathrm{kg} \mathrm{CO} 2 \mathrm{eq})$ & 9.1 & $-26.3 \%$ & 8.3 & $-22.8 \%$ & 7.4 & $-7.0 \%$ \\
\hline $\mathrm{GWP}_{\mathrm{b}}(\mathrm{kg} \mathrm{CO} 2 \mathrm{eq})$ & $8.8 \times 10^{-1}$ & $-31.8 \%$ & $8.0 \times 10^{-1}$ & $-28.4 \%$ & $6.8 \times 10^{-1}$ & $-13.4 \%$ \\
\hline $\begin{array}{c}\mathrm{GWP}_{\text {LULUC }}(\mathrm{kg} \\
\left.\mathrm{CO}_{2 \mathrm{eq}}\right)\end{array}$ & $5.6 \times 10^{-3}$ & $-33.4 \%$ & $5.3 \times 10^{-3}$ & $-28.1 \%$ & $3.8 \times 10^{-3}$ & $-11.3 \%$ \\
\hline
\end{tabular}

In RBS, the energy saved in the operational phase allows to improve the environmental performances of the retrofitted building apartment in almost all the examined categories compared to the BBS. The exceptions are:

- $\quad \mathrm{AP}$, in which the impact in RBS increases by a minimum value equal to about $10 \%$ (for both CfS and SwS, 1945-1969) up to about 30\% (for both CfS and SwS, 1990-2010);

- $\mathrm{ADP}_{\mathrm{m} \& \mathrm{~m}}$, in which the impact in RBS increases by a minimum value equal to about 5\% (for CfS, 1945-1969) up to about 14\% (for CfS, 1990-2010);

- Ionizing radiation (IR) and $\mathrm{EP}_{\mathrm{FW}}$, in which the impact in $\mathrm{RBS}$ increases by about $6 \%$ for both CfS and SwS in 1990-2010 construction period;

- HT-ce, in which the impact in RBS increases by 5\% in SwS in 1990-2010 construction period;

- WU, in which the contribution to the impact increases of about $5 \%$ in RBS.

In both RBS (CfS and SwS), the contribution to AP, $\mathrm{ADP}_{\mathrm{m} \& \mathrm{~m}}$, IR and HT-ce increases compared to BBS. This is due to the embodied impacts of the materials employed (B5 and $\mathrm{C}$ modules) that are higher than environmental benefits caused by the energy savings in the buildings operational phase. This outcome highlights the importance to assess the strategies planned towards the sustainable development through a life cycle perspective since analyses focused only on the operational phase could provide partial and misleading results.

Figures 6 and 7 illustrate the contribution of each life cycle phase included within the expanded system boundaries ( $\mathrm{FU}_{\mathrm{ES}}$ ) to the total impacts of the buildings realized in 1945-1969 construction period for CfS and SwS, respectively. The analysis highlights that the buildings operational phase contributes by more than $70 \%$ in all the impact categories examined. In the CfS, the retrofit intervention (B5) has a large impact only on AP (about 
25\%) and $\mathrm{ADP}_{\mathrm{m} \& \mathrm{~m}}$ (about 20\% for 1945-1969 and 1969-1989 construction periods, $14 \%$ for 1990-2010 construction period) categories. In the SwS, the B5 module causes large impacts on:

- $\mathrm{AP}$, in which it contributes for about $25 \%$ of the total impact in all the examined configurations;

- HT-ce, in which it contributes for about $18 \%$ in the cases of buildings constructed in the 1945-1969 and 1969-1989 construction periods and for about 14\% for those built in the 1990-2010 construction period.

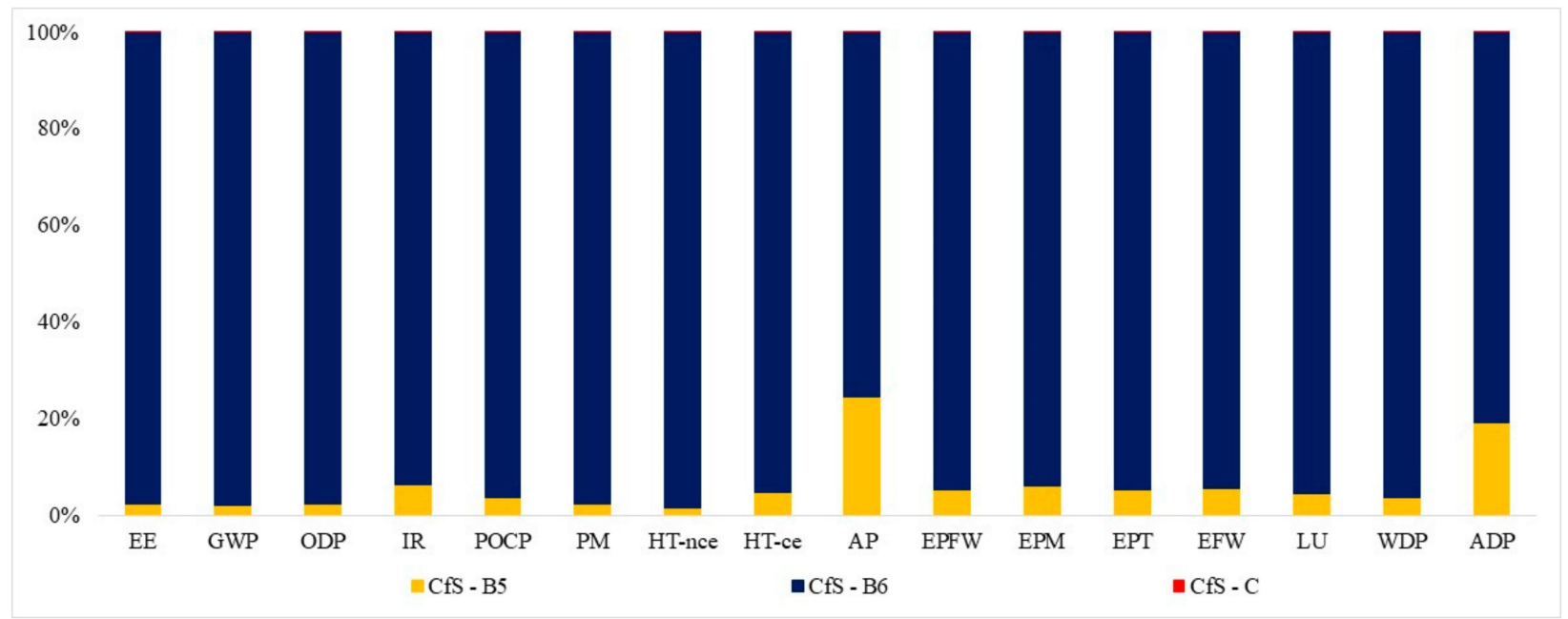

Figure 6. Contribution of the different phases to the life cycle impacts—CfS (1945-1969).

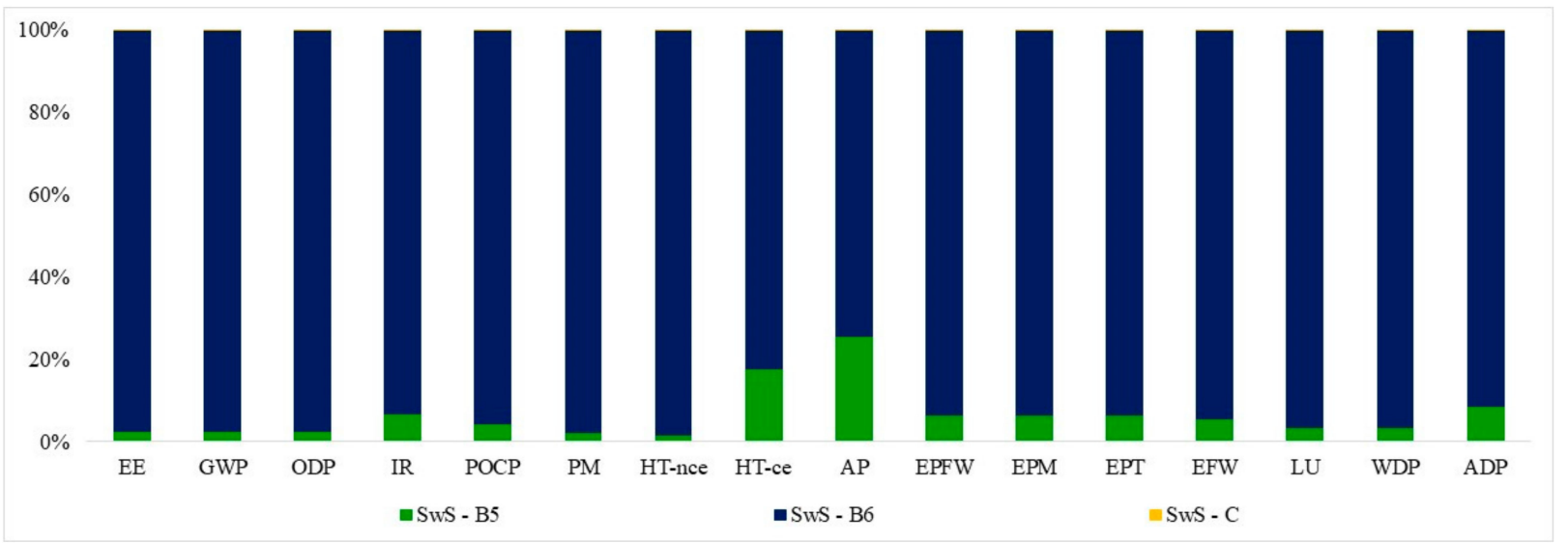

Figure 7. Contribution of the different phases to the life cycle impacts—SwS (1945-1969).

The contribution analysis results for the other construction periods are reported in Appendix A (Figure A5 for CfS, 1970-1989; Figure A6 for CfS, 1990-2010, Figure A7 for SwS, 1970-1989 and Figure A8 for SwS, 1990-2010).

Concerning the energy and environmental benefits of the retrofit scenarios compared with the BBS, in both CfS and SwS higher values are obtained by retrofitting building apartments built in the 1945-1969 and 1970-1989 construction periods. In detail, the impact decreases by percentages ranging from a minimum value of about $16 \%$ (for $\mathrm{EP}_{\mathrm{T}}, 1970-1989$ ) up to about 37\% (for PM, 1945-1969) in all categories with the exceptions of IR and EP $P_{F W}$, in which the impacts decrease by less than $4 \%$ in both CfS and SwS. The energy and environmental benefits decrease in the case of buildings realized in the 1990-2010, since this building has higher performance compared with those realized in 1945-1969 and 1979-1989 construction periods. The energy savings achieved through the retrofit actions 
allow to reduce the impacts caused by the operational phase (B6 module) in almost all the categories except for WU, in which the impacts increase of a negligible percentage (lower than $3 \%$ ) in retrofitted buildings due to the increased consumption of energy for cooling (Table 2). In the other categories the impacts associated with the B6 module decrease by an average percentage of about $28 \%$ for building belonging to $1945-1969$ construction period, of about $24 \%$ for those built in the 1979-1989 construction period and finally of about $10 \%$ for those built in the 1990-2010 construction period. This result leads to a recommendation of giving priority to the oldest buildings in the retrofit schedule plan.

\subsection{Payback Times}

Table 7 shows the energy and environmental payback time indices of the retrofit action evaluated for both CfS and SwS. Data analysis highlights that in the CfS the energy and environmental impacts associated to the retrofit action can be repaid in less than 2 years in all the impact categories examined except for $\mathrm{AP}$ and $\mathrm{ADP}_{\mathrm{m} \& \mathrm{~m}}$., for which up to about 10 years and 6.5 years are needed. Concerning the SwS, the highest payback time indices are obtained in correspondence of HT-ce (up to about 5 years) and AP (up to about 10 years). In the other energy and environmental impact categories are repaid in less thar 3 years.

Table 7. Energy and environmental payback times of the retrofit action-CfS and SwS.

\begin{tabular}{|c|c|c|c|c|c|c|}
\hline $\begin{array}{l}\text { Impact } \\
\text { Category }\end{array}$ & $\begin{array}{c}\text { CfS } \\
\text { 1945-1969 } \\
\text { (Years) }\end{array}$ & $\begin{array}{c}\text { CfS } \\
\text { 1970-1989 } \\
\text { (Years) }\end{array}$ & $\begin{array}{c}\text { CfS } \\
\text { 1990-2010 } \\
\text { (Years) }\end{array}$ & $\begin{array}{c}\text { SwS } \\
\text { 1945-1969 } \\
\text { (Years) }\end{array}$ & $\begin{array}{c}\text { SwS } \\
\text { 1970-1989 } \\
\text { (Years) }\end{array}$ & $\begin{array}{c}\text { SwS } \\
\text { 1990-2010 } \\
\text { (Years) }\end{array}$ \\
\hline$I P B_{T, E E}$ & 0.47 & 0.53 & 0.67 & 0.52 & 0.58 & 0.71 \\
\hline$I P B_{T, G W P}$ & 0.42 & 0.47 & 0.59 & 0.58 & 0.65 & 0.72 \\
\hline$I P B_{T, O D P}$ & 0.53 & 0.60 & 0.71 & 0.57 & 0.65 & 0.74 \\
\hline$I P B_{T, I R}$ & 1.81 & 2.10 & 1.76 & 1.95 & 2.27 & 1.85 \\
\hline$I P B_{T, P O F}$ & 0.72 & 0.80 & 1.19 & 0.85 & 0.95 & 1.33 \\
\hline$I P B_{T, P M}$ & 0.42 & 0.47 & 0.78 & 0.43 & 0.48 & 0.79 \\
\hline$I P B_{T, H T-n c e}$ & 0.30 & 0.33 & 0.48 & 0.30 & 0.33 & 0.48 \\
\hline$I P B_{T, H T-c e}$ & 1.08 & 1.19 & 1.30 & 4.68 & 5.14 & 4.28 \\
\hline$I P B_{T, A P}$ & 7.91 & 9.18 & 9.50 & 8.45 & 9.78 & 9.87 \\
\hline$I P B_{T, E P F W}$ & 1.55 & 1.78 & 1.37 & 1.90 & 2.20 & 1.58 \\
\hline$I P B_{T, E P M}$ & 1.44 & 1.63 & 1.83 & 1.51 & 1.72 & 1.89 \\
\hline$I P B_{T, E P T}$ & 1.29 & 1.45 & 1.56 & 1.60 & 1.81 & 1.80 \\
\hline$I P B_{T, E F W}$ & 1.16 & 1.29 & 1.75 & 1.20 & 1.35 & 1.80 \\
\hline$I P B_{T, L U}$ & 0.89 & 0.98 & 1.39 & 0.66 & 0.74 & 1.15 \\
\hline$I P B_{T, W U}$ & 1.11 & 1.29 & 0.85 & 1.07 & 1.26 & 0.83 \\
\hline$I P B_{T,} A D P m \mathcal{E} m$ & 6.03 & 6.62 & 4.79 & 2.39 & 2.76 & 2.49 \\
\hline
\end{tabular}

\section{Conclusions}

In the context of the building renovation wave initiative promoted by the European Commission, this research assesses the energy and environmental impacts related to the improvement of the thermal insulation of residential building apartments and to evaluate the achievable net benefits compared with non-retrofitted ones. Two different thermal insulation materials are examined and compared in a life cycle perspective: cellulose fibers (bio-based material) and stone wool (conventional insulation material). Apartments built in three different periods-1945-1969, 1970-1989, 1990-2010—are analyzed. The study highlights that the employment of the cellulose fibers as thermal insulation material causes lower impacts than those due to the employment of the stone wool in most of the energy and environmental categories investigated, with a percentage variation ranging from $4 \%$ to $154 \%$. Retrofitting buildings with the bio-based insulation material allows for reducing the impact on global warming potential providing a positive contribution to meet climate change goals. In detail, the impact in this category decreases of percentage ranging from about $12 \%$ to $20 \%$ compared to stone wool use. However, cellulose fibers cause higher impact on depletion of abiotic resources-material and metals, which is a key indicator to 
measure the circularity of strategies. Therefore, it is paramount to identify more sustainable production route for cellulose fibers insulation material in terms of resource consumption.

The contribution analysis of the retrofit intervention clarifies that the substitution of the gypsum plasterboard layer affects for more than $50 \%$ the impacts to the categories examined, in both cellulose fibers and stone wool scenarios. Then, a significant reduction of the embodied impacts of the retrofit action investigated can be achieved by increasing the rate of recycled construction materials or identifying alternative design solution for building envelope.

The evaluation of the net energy and environmental benefits in the retrofitted building apartments compared with the non-retrofitted ones show that in both scenarios (cellulose fibers and stone wool), the energy saved in the operational phase can improve the environmental performance in most impact categories. The payback time indices evaluated show that the life cycle impacts related to the retrofit action are repaid in less than three years in most impact categories. Further efforts are required in order to achieve environmental benefits also in terms of acidification, depletion of abiotic resources (material and metals), ionizing radiation, freshwater ecotoxicity, human toxicity/cancer effects, and water use. An electricity mix characterized by a high share of renewables can allow to increase the energy and environmental benefits associated with retrofits. However, a strategy involving the production processes and the end-of-life treatments of the employed materials is recommended.

Concerning the buildings construction period, the research highlights that the proposed retrofit action is less effective for buildings of the 1990-2010 period. The oldest buildings have low thermophysical performance so higher net environmental benefits can be achieved relative to the retrofit target assumed.

Author Contributions: Conceptualization, all authors; Methodology, all authors; Software, M.A.C. and T.M.G.; Validation, M.C. and M.M.; Formal analysis, M.A.C. and T.M.G.; Investigation, M.A.C. and T.M.G.; Resources, M.A.C. and T.M.G.; Data curation, all authors; Writing-original draft preparation, M.A.C.; Writing - review and editing, M.C. and M.M.; Visualization, M.A.C.; Supervision, M.C. and M.M. All authors have read and agreed to the published version of the manuscript.

Funding: This research received no external funding.

Institutional Review Board Statement: Not applicable.

Informed Consent Statement: Not applicable.

Conflicts of Interest: The authors declare no conflict of interest.

\section{Nomenclature}

$\begin{array}{ll}\text { ADP }_{m \& m} & \text { Depletion of abiotic resources-material and metals } \\ \text { AP } & \text { Acidification } \\ \text { BBS } & \text { Baseline building } \\ \text { CED } & \text { Cumulative energy demand } \\ \text { CfS } & \text { Cellulose fibers scenario } \\ \mathrm{EE} & \text { Embodied energy } \\ \mathrm{EE} & \text { Embodied energy, non-renewable } \\ \mathrm{EE}_{\mathrm{r}} & \text { Embodied energy, renewable } \\ \mathrm{E}_{\mathrm{FW}} & \text { Eco-toxicity (freshwater) } \\ \mathrm{EOL} & \text { End-of-life } \\ \mathrm{EPBD} & \text { Energy Performance of Buildings Directive } \\ \mathrm{EP} & \text { Eutrophication aquatic freshwater } \\ \mathrm{EP} & \text { Eutrophication aquatic marine } \\ \mathrm{EP}_{\mathrm{T}} & \text { Eutrophication terrestrial } \\ \mathrm{EU} & \text { European Union } \\ \mathrm{FU} & \text { Functional unit } \\ \mathrm{FU} & \text { Functional unit for life cycle impact saving assessment }\end{array}$




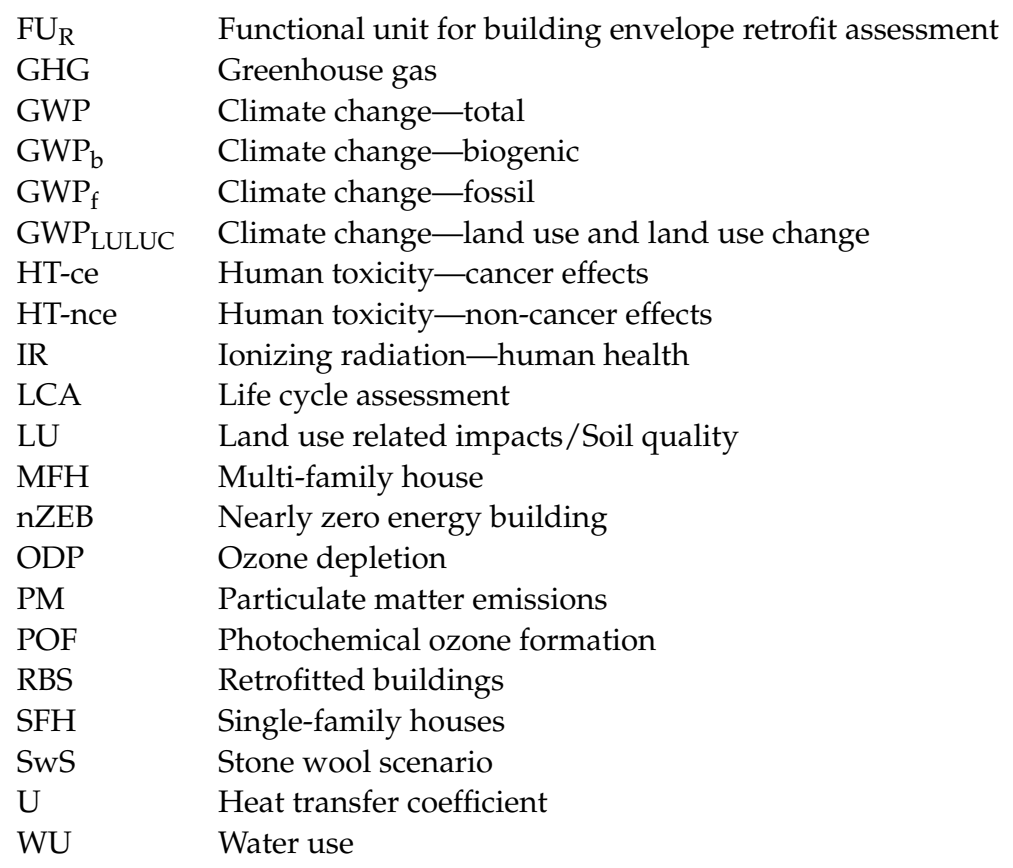

Appendix A

Appendix A.1. Life Cycle Impact Assessment of the Retrofit Intervention

Figures A1 and A2 illustrate the contribution analysis results of the different life cycle phases to the B5 module impacts in the case of buildings realized between 1970 and 1989 and between 1990 and 2010 in CfS, respectively.

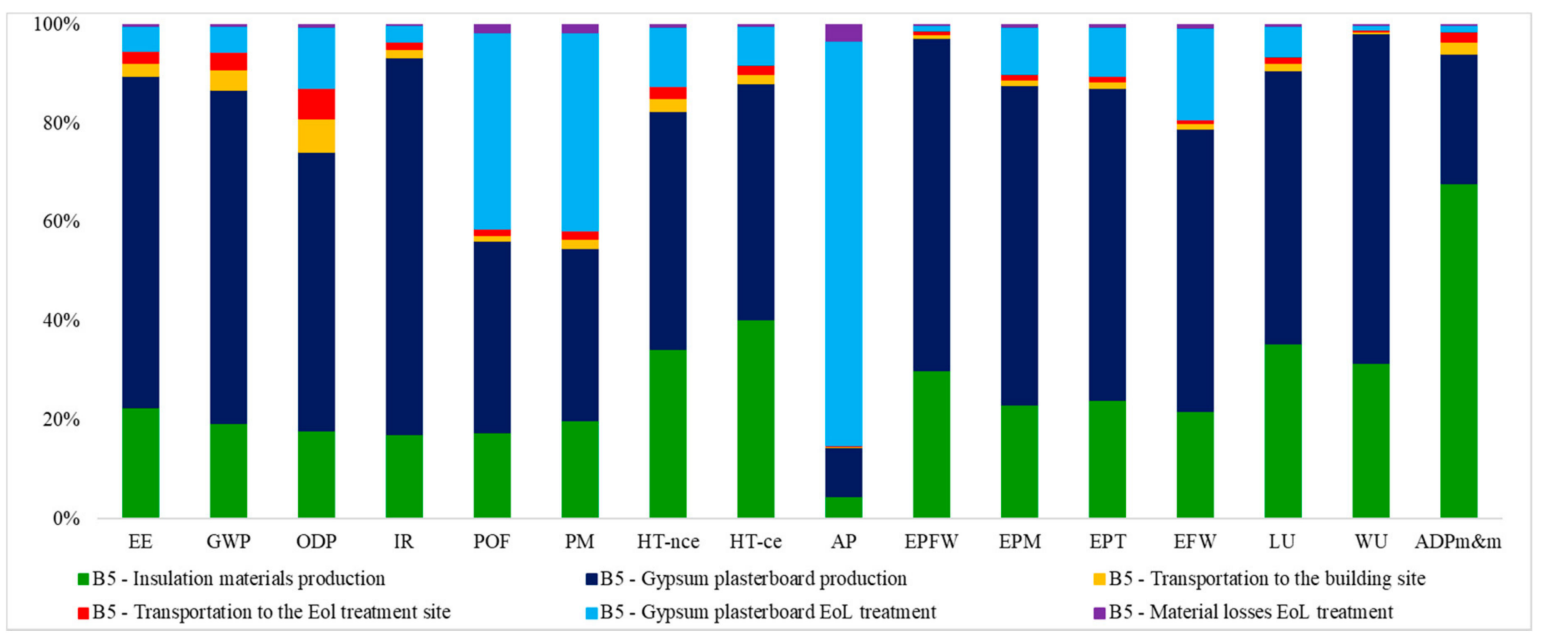

Figure A1. Contribution of the different life cycle phases to the B5 module impacts-CfS (1970-1989). 


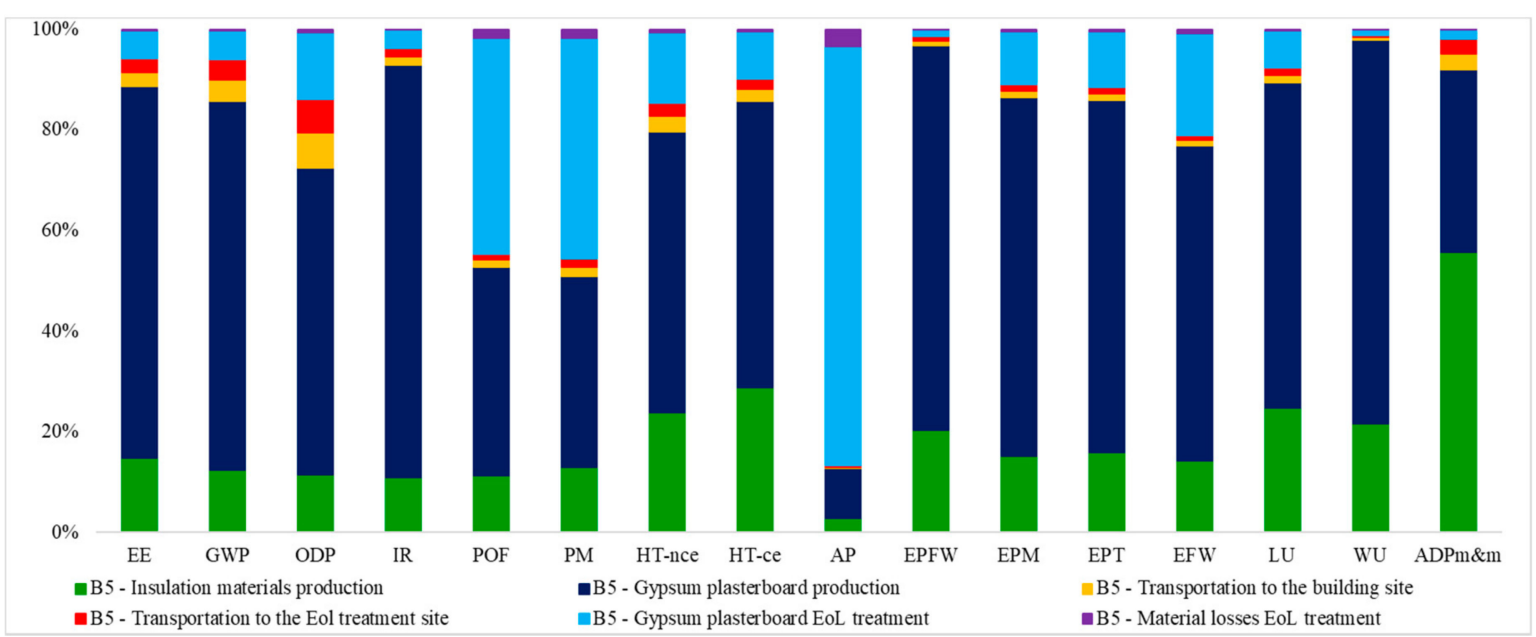

Figure A2. Contribution of the different life cycle phases to the B5 module impacts-CfS (1990-2010).

Figures A3 and A4 illustrate the contribution analysis results of the different life cycle phases to the B5 module impacts in the case of buildings realized between 1970 and 1989 and between 1990 and 2010 in SwS, respectively.

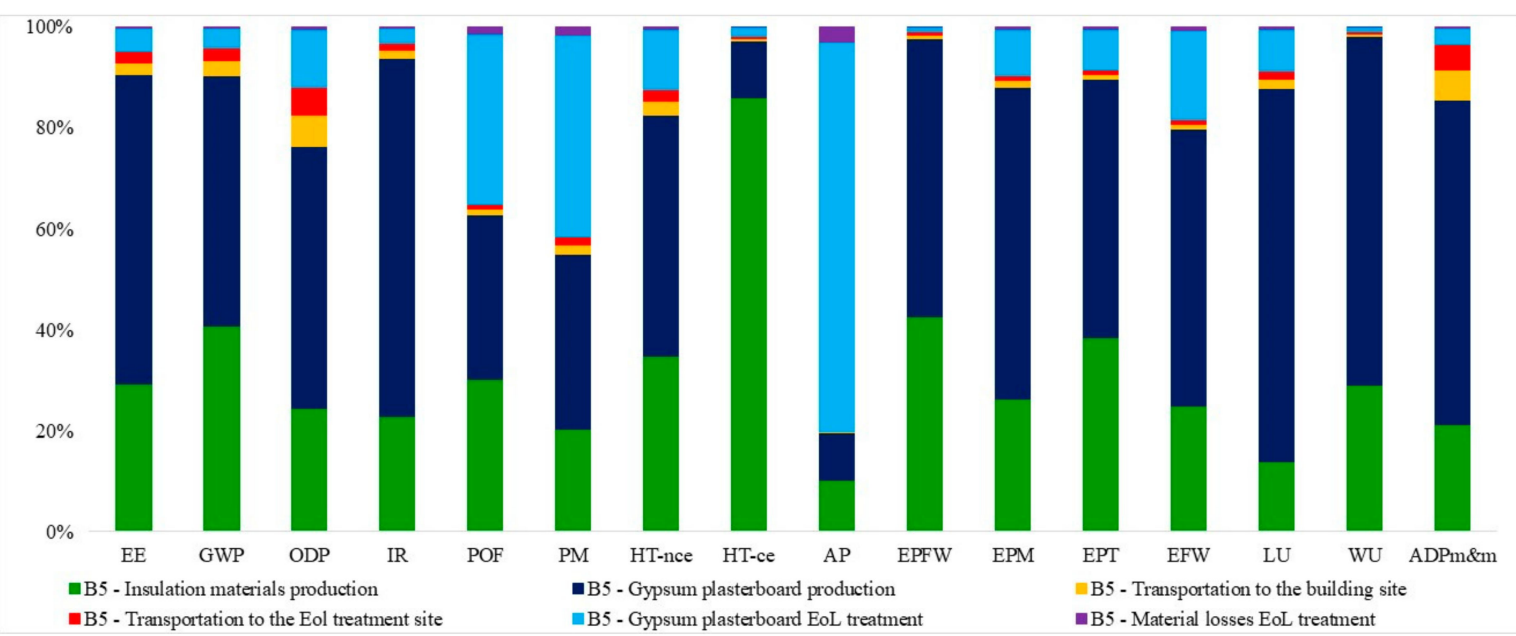

Figure A3. Contribution of the different life cycle phases to the B5 module impacts-SwS (1970-1989).

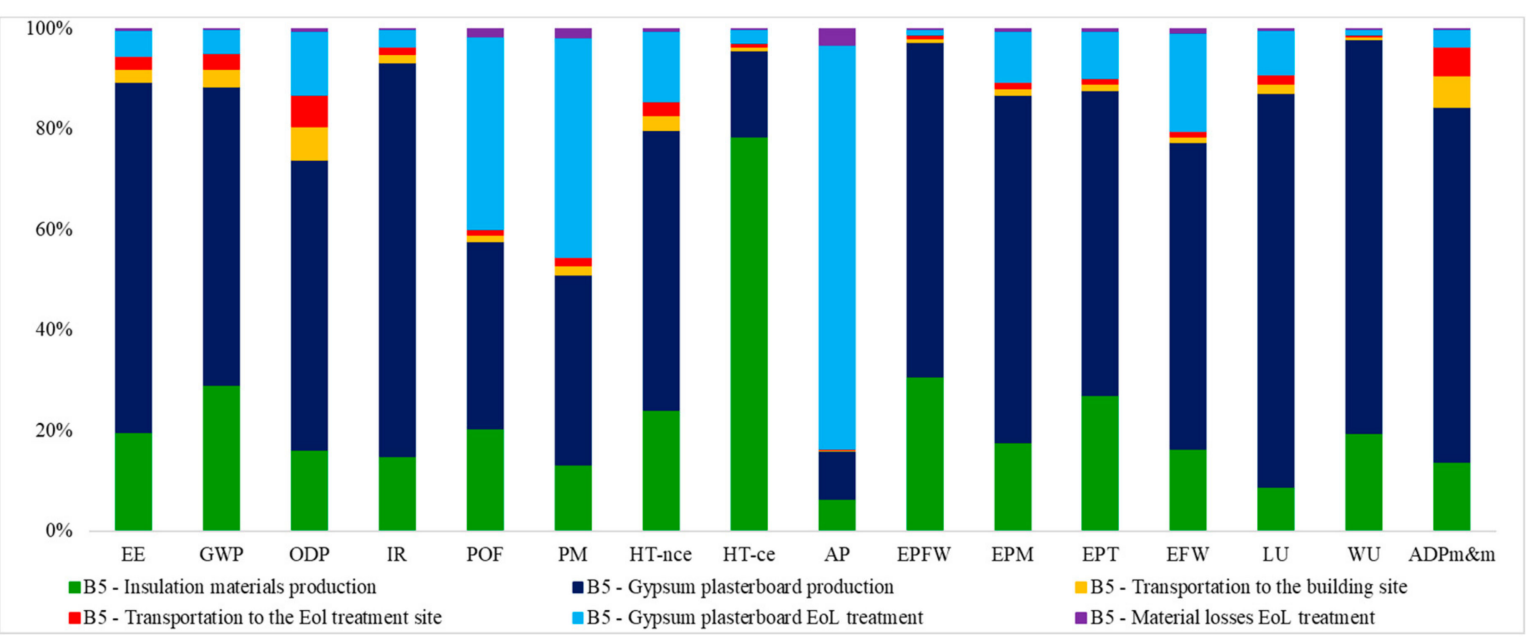

Figure A4. Contribution of the different life cycle phases to the B5 module impacts-SwS (1990-2010). 
Appendix A.2. Life Cycle Impact Assessment: Comparison of the Retrofitted and Non-Retrofitted Buildings

Figures A5 and A6 illustrate the contribution of each life cycle phase included within the expanded system boundaries ( $\mathrm{FU}_{\mathrm{ES}}$ ) for CfS, for the buildings realized in 1970-1989 and in 1990-2010 construction periods, respectively.

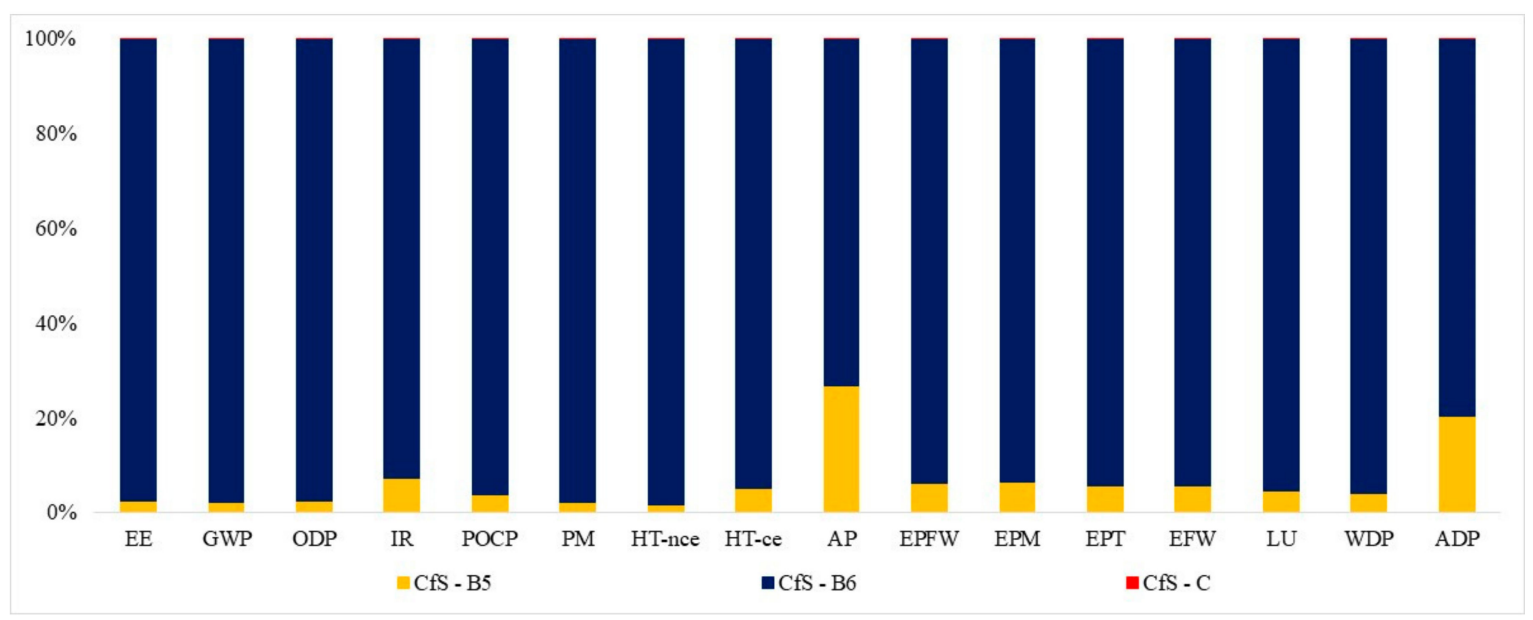

Figure A5. Contribution of the different phases to the life cycle impacts-CfS (1970-1989).

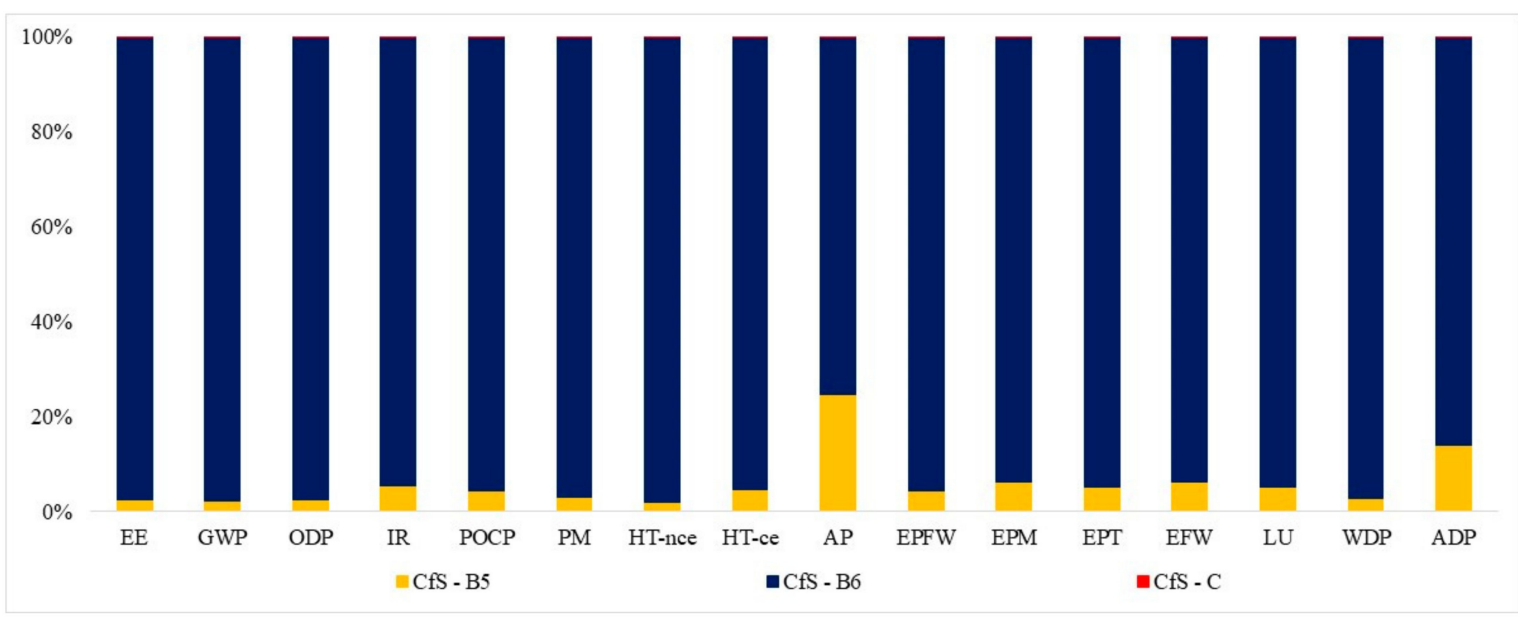

Figure A6. Contribution of the different phases to the life cycle impacts-CfS (1990-2010).

Figures A7 and A8 illustrate the contribution of each life cycle phase included within the expanded system boundaries ( $\mathrm{FU}_{\mathrm{ES}}$ ) for $\mathrm{SwS}$, for the buildings realized in 1970-1989 and in 1990-2010 construction periods, respectively. 


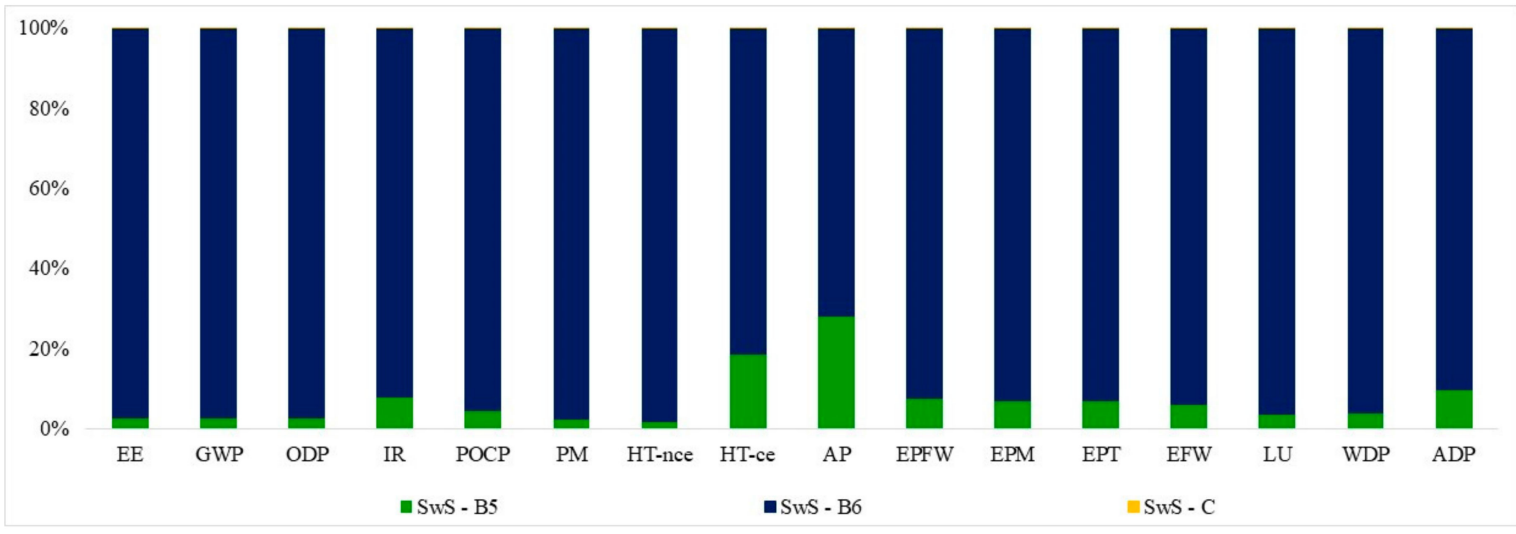

Figure A7. Contribution of the different phases to the life cycle impacts—SwS (1970-1989).

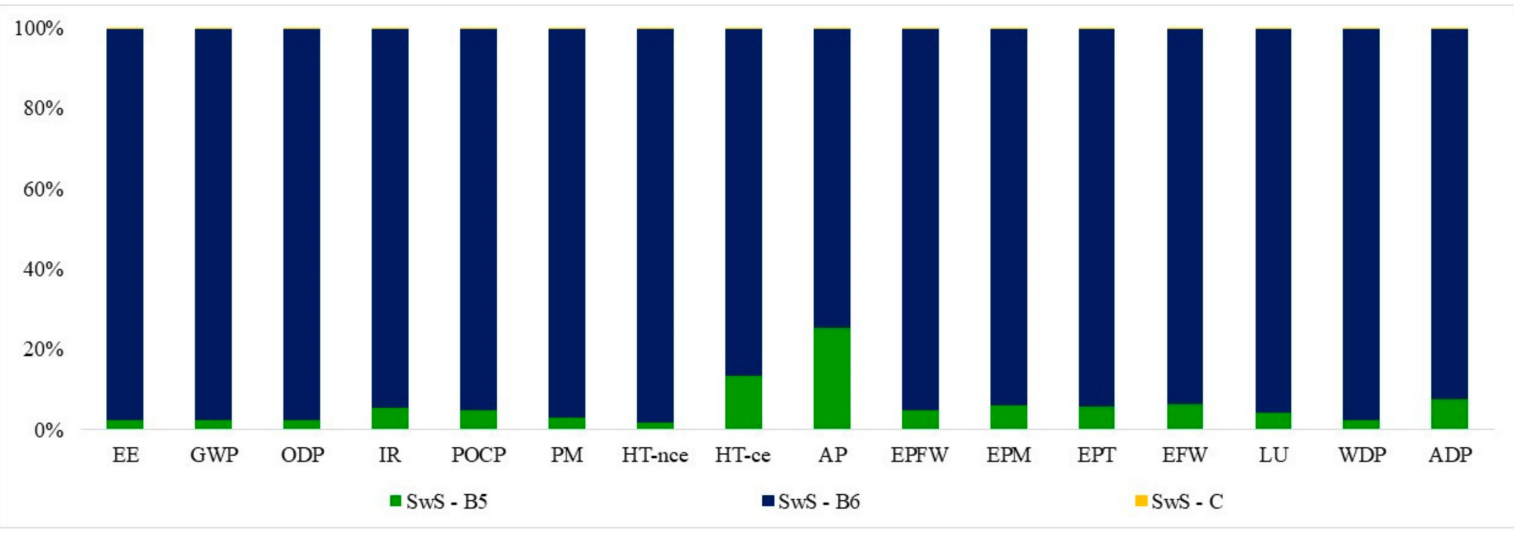

Figure A8. Contribution of the different phases to the life cycle impacts-CfS (1990-2010).

\section{References and Notes}

1. European Union. Directive 2018/844/UE of the European Parliament and of Council, 30 May 2018 amending Directive 2010/31/EU on the Energy Performance of Buildings and Directive 2012/27/EU on Energy Efficiency (Text with EEA Relevance). 2018. Available online: https: / eur-lex.europa.eu/eli/dir/2018/844/oj (accessed on 9 June 2021).

2. European Commission. Roadmap to a Resource Efficient Europe-COM(2011) 571 Final; European Commission: Luxembourg, 2011.

3. European Construction Sector Observatory. Analytical Report-Improving Energy and Resource Efficiency; European Commission: Luxembourg, 2018.

4. European Commission. Stepping up Europe's 2030 Climate Ambition. Investing in a Climate-Neutral Future for the Benefit of Our People; 17.9.2020 COM(2020) 562 Final 2020; European Commission: Brussels, Belgium, 2020.

5. European Commission. Communication from the European Commission. The European Green Deal; 11.12.2019, COM(2019) 640 Final; European Commission: Brussels, Belgium, 2019.

6. Fichera, A.; Pluchino, A.; Volpe, R. From self-consumption to decentralized distribution among prosumers: A model including technological, operational and spatial issues. Energy Convers. Manag. 2020, 217, 112932. [CrossRef]

7. Hachem-Vermette, C.; Guarino, F.; la Rocca, V.; Cellura, M. Towards achieving net-zero energy communities: Investigation of design strategies and seasonal solar collection and storage net-zero. Sol. Energy 2019, 192, 169-185. [CrossRef]

8. Caputo, P.; Zagarella, F.; Cusenza, M.A.; Mistretta, M.; Cellura, M. Energy-environmental assessment of the UIA-OpenAgri case study as urban regeneration project through agriculture. Sci. Total. Environ. 2020, 729, 138819. [CrossRef] [PubMed]

9. European Commission. A Renovation Wave for Europe-Greening Our Buildings, Creating Jobs, Improving Lives; COM(2020) 662; European Commission: Luxembourg, 2020.

10. Sala, S.; Reale, F.; Cristobal-Garcia, J.; Marelli, L.; Pant, R. Life Cycle Assessment for the Impact Assessment of Policies; 28380 EN; Publications Office of the European Union: Luxembourg, 2016. [CrossRef]

11. Cusenza, M.A.; Guarino, F.; Longo, S.; Mistretta, M.; Cellura, M. Environmental assessment of 2030 electricity generation scenarios in Sicily: An integrated approach. Renew. Energy 2020, 160, 1148-1159. [CrossRef]

12. ISO. EN ISO 14040:2006/A1:2020. Environmental Management-Life Cycle Assessment-Principles and FrameworkAmendment 1 (ISO 14040:2006/Amd 1:2020) 2020. 
13. ISO. EN ISO 14044:2006/A2:2020. Environmental Management—Life Cycle Assessment-Requirements and GuidelinesAmendment 2 (ISO 14044:2006/Amd 2:2020) 2020.

14. European Commission. Communication from the Commission to the European Parliament, the European Council, the Council, the European Economic and Social Committee and the Committee of the Regions. In A Sustainable Bioeconomy for Europe: Strengthening the Connection Between Economy; European Commission: Luxembourg, 2018. [CrossRef]

15. Cabeza, L.F.; Rincón, L.; Vilariño, V.; Pérez, G.; Castell, A. Life cycle assessment (LCA) and life cycle energy analysis (LCEA) of buildings and the building sector: A review. Renew. Sustain. Energy Rev. 2014, 29, 394-416. [CrossRef]

16. Llantoy, N.; Chàfer, M.; Cabeza, L.F. A comparative life cycle assessment (LCA) of different insulation materials for buildings in the continental Mediterranean climate. Energy Build. 2020, 225, 110323. [CrossRef]

17. Sierra-Pérez, J.; Boschmonart-Rives, J.; Gabarrell, X. Environmental assessment of façade-building systems and thermal insulation materials for different climatic conditions. J. Clean. Prod. 2016, 113, 102-113. [CrossRef]

18. Beccali, M.; Cellura, M.; Fontana, M.; Longo, S.; Mistretta, M. Energy retrofit of a single-family house: Life cycle net energy saving and environmental benefits. Renew. Sustain. Energy Rev. 2013. [CrossRef]

19. Ardente, F.; Beccali, M.; Cellura, M.; Mistretta, M. Building energy performance: A LCA case study of kenaf-fibres insulation board. Energy Build. 2008. [CrossRef]

20. Gulotta, T.M.; Cellura, M.; Guarino, F.; Longo, S. A bottom-up harmonized energy-environmental models for europe (BOHEEME): A case study on the thermal insulation of the EU-28 building stock. Energy Build. 2021, 231. [CrossRef]

21. European Union. Directive 2010/31/EU of the European Parliament and of the Council of 19 May 2010 on the Energy Performance of Buildings (Recast). 2010. Available online: https:/ / eur-lex.europa.eu/eli/dir/2010/31/oj (accessed on 9 June 2021).

22. Baldassarri, C.; Allacker, K.; Reale, F.; Castellani, V.; Sala, S. Consumer Footprint. Basket of Products Indicator on Housing; EUR 28765 EN; JRC107958; Publications Office of the European Union: Luxembourg, 2017. [CrossRef]

23. Eurostat. Distribution of Population by Degree of Urbanisation, Dwelling Type and Income Group-EU-SILC Survey. 2020. Available online: https: / / ec.europa.eu/eurostat/web/products-datasets/- /ILC_LVHO01 (accessed on 21 May 2021).

24. CEN/TC 350. EN 15804:2012+A2:2019 'Sustainability of Construction Works—Environmental Product Declarations-Core Rules for the Product Category of Construction Products'. 2019.

25. CEN/TC 350. EN 15978: 2011-Sustainability of construction works-Assessment of environmental performance of buildingsCalculation method. International Standard 2011.

26. Althaus, H.-J.; Doka, G.; Dones, R.; Hischier, R.; Hellweg, S.; Humbert, S.; Margini, M.; Nemecek, T.; Spielmann, M. Implementation of Life Cycle Impact Assessment Methods. Am. Midl. Nat. 2007, 150, 1-151.

27. Fazio, S.; Castellani, V.; Sala, S.; Schau, E.; Secchi, M.; Zampori, L. Supporting Information to the Characterisation Factors of Recommended EF Life Cycle Impact Assessment Methods; EUR 28888 EN; European Commission: Ispra, Italy, 2018; ISBN 978-92-7976742-5. JRC109369. [CrossRef]

28. PRéConsultants. SimaPro. v. 9.1.0.8. Available online: https://simapro.com/2020 (accessed on 21 May 2021).

29. ISO. UNI 10351:2015-Building Materials and Products-Hygrothermal Proprieties—Procedure for Determining the Design Values. 2015.

30. Asdrubali, F.; Baldassarri, C.; Fthenakis, V. Life cycle analysis in the construction sector: Guiding the optimization of conventional Italian buildings. Energy Build. 2013, 64, 73-89. [CrossRef]

31. Lavagna, M.; Baldassarri, C.; Campioli, A.; Giorgi, S.; Dalla Valle, A.; Castellani, V.; Sala, S. Benchmarks for environmental impact of housing in Europe: Definition of archetypes and LCA of the residential building stock. Build. Environ. 2018, 145, 260-275. [CrossRef]

32. DoE US. Energyplus Engineering Reference. The Reference to Energyplus Calculations. 2010. Available online: https:// energyplus.net/ (accessed on 9 June 2021).

33. Mantzos, L.; Wiesenthal, T.; Matei, N.-A.; Tchung-Ming, S.; Rozsai, M.; Russ, H.P.; Ramirez, A.S. JRC-IDEES: Integrated Database of the European Energy Sector; Methodological Note; Publications Office of the European Union: Luxembourg, 2017. [CrossRef]

34. Wernet, G.; Bauer, C.; Steubing, B.; Reinhard, J.; Moreno-Ruiz, E.; Weidema, B. The ecoinvent database version 3 (part I): Overview and methodology. Int. J. Life Cycle Assess. 2016, 21, 1218-1230. [CrossRef]

35. European Commission. Communication from the Commission to the European Parliament, the Council, the European Economic and Social Committee and the Committee of the Regions on the 2017 List of Critical Raw Materials for the Eu; COM(2017) 490 Final 2017; European Commission: Luxembourg, 2017.

36. Donmez Cavdar, A.; Boran Torun, S.; Ertas, M.; Mengeloglu, F. Ammonium zeolite and ammonium phosphate applied as fire retardants for microcrystalline cellulose filled thermoplastic composites. Fire Saf. J. 2019, 107, 202-209. [CrossRef] 